\title{
Обзоры
}

Пространственная Экономика 2021. Том 17. № 2. C. $81-126$

JEL: L19, P25, R12

https://dx.doi.org/10.14530/se.2021.2.081-126

УДК $338+332$

\section{Экономическая коньюнктура}

в $\triangle$ альневосточном феgеральном оkруге

B 2020 r.

\author{
О.М. Прокапа^о, А.Б. Барgа^ь, А.Г. Исаев, \\ М.Г. Мазитова, $\triangle$.В. Суслов
}

\author{
Прокапало Ольга Михайловна \\ доктор экономических наук \\ врио директор \\ Институт экономических исследований ДВО РАН, ул. Тихоокеанская, 153, Хабаровск, \\ 680042, Российская Федерация \\ E-mail: prokapalo@ecrin.ru \\ ORCID: 0000-0002-7570-397X
}

Бардаль Анна Борисовна кандидат экономических наук, доцент

ведущий научный сотрудник

Институт экономических исследований ДВО РАН, ул. Тихоокеанская, 153, Хабаровск, 680042, Российская Федерация

E-mail: Bardal@ecrin.ru

ORCID: 0000-0002-9944-4714

Исаев Артем Геннадьевич

кандидат экономических наук

ведущий научный сотрудник

Институт экономических исследований ДВО РАН, ул. Тихоокеанская, 153, Хабаровск, 680042, Российская Федерация

E-mail: isaev@ecrin.ru

ORCID: 0000-0001-6569-2982

Мазитова Марина Гамиловна

научный сотрудник

Институт экономических исследований ДВО РАН, ул. Тихоокеанская, 153, Хабаровск, 680042, Российская Федерация

E-mail: mazitova@ecrin.ru

ORCID: 0000-0002-7978-7904

Суслов Денис Владимирович

кандидат экономических наук

старший научный сотрудник

Институт экономических исследований ДВО РАН, ул. Тихоокеанская, 153, Хабаровск, 680042, Российская Федерация

E-mail: suslov@ecrin.ru

ORCID: 0000-0001-5866-4369

(с) Прокапало О.М., Бардаль А.Б., Исаев А.Г., Мазитова М.Г., Суслов Д.В., 2021 
Аннотащия. В статье содержится анализ тенденций социально-экономического развития ДФО в 2020 г. в разрезе административно-территориальных регионов и основных видов экономической деятельности на основе оперативной статистической, аналитической и экспертной информации. Рассматриваются проблемы функционирования отраслей реального сектора экономики, социальной сферы, внешнеэкономической деятельности в условиях неопределенности на нефтяном и валютном рынках, а также введения карантинных и ограничительных мер в связи с распространением коронавирусной инфекции. Отмечается сокращение объема инвестиционных ресурсов в Амурской и Сахалинской областях, Приморском крае, Республике Саха (Якутия), которые являются основными «инвестиционноемкими» регионами ДФО. Сохраняется существенная отраслевая асимметрия в привлечении прямых иностранных инвестиций, основная часть которых концентрируется в геологоразведке и добыче топливно-энергетических полезных ископаемых, а также снижение объемов производства в промышленном комплексе макрорегиона, особенно затронув деятельность предприятий машиностроения, нефтепереработки, промышленности строительных материалов в Приморском и Хабаровском краях. Невыполнение планов развития инфраструктуры железных дорог Восточного полигона привело к ограничениям грузоперевозок. Сокращение реальных денежных доходов населения становится фактором снижения привлекательности Дальнего Востока. Продолжается процесс снижения численности населения ДФО не только за счет миграционного оттока, но и естественной убыли в результате как факторов объективного снижения рождаемости, так и социальных и экономических последствий пандемии.

Ключевые слова: мониторинг, ВРП, промышленное производство, инвестиции, инфляция, рынок труда, уровень жизни, внешняя торговля, иностранные инвестиции, Дальневосточный федеральный округ

Для ичитирования: Прокапало О.М., Бардаль А.Б., Исаев А.Г., Мазитова М.Г., Суслов Д.В. Экономическая конъюнктура в Дальневосточном федеральном округе в 2020 г. // Пространственная экономика. 2021. № 2. С. 81-126. https://dx.doi.org/10.14530/se.2021.2.081-126

\section{Economic Situation in the Far Eastern Federal District in 2020}

\section{O.M. Prokapalo, A.B. Bardal, A.G. Isaev, M.G. Mazitova, D.V. Suslov}

Olga Mikhailovna Prokapalo

Doctor of Economics

Director

Economic Research Institute FEB RAS, 153 Tikhookeanskaya St., Khabarovsk, 680042, Russian Federation

E-mail: prokapalo@ecrin.ru

ORCID: 0000-0002-7570-397X

Anna Borisovna Bardal

Candidate of Sciences (Economics)

Assistant Professor

Leading Research Fellow

Economic Research Institute FEB RAS, 153 Tikhookeanskaya St., Khabarovsk, 680042, Russian Federation

E-mail: Bardal@ecrin.ru

ORCID: 0000-0002-9944-4714 
Artyom Gennadyevich Isaev

Candidate of Sciences (Economics)

Leading Research Fellow

Economic Research Institute FEB RAS, 153 Tikhookeanskaya St., Khabarovsk, 680042,

Russian Federation

E-mail: isaev@ecrin.ru

ORCID: 0000-0001-6569-2982

\section{Marina Gamilovna Mazitova}

Research Fellow

Economic Research Institute FEB RAS, 153 Tikhookeanskaya St., Khabarovsk, 680042,

Russian Federation

E-mail: mazitova@ecrin.ru

ORCID: 0000-0002-7978-7904

Denis Vladimirovich Suslov

Candidate of Sciences (Economics)

Senior Research Fellow

Economic Research Institute FEB RAS, 153 Tikhookeanskaya St., Khabarovsk, 680042, Russian Federation

E-mail: suslov@ecrin.ru

ORCID: 0000-0001-5866-4369

Abstract. The article includes an analysis of the most significant trends in the socio-economic development of the Far Eastern Federal District in 2020 in the context of administrative units and main types of economic activity. The analysis is based on advanced statistical, analytical, and expert information. The article considers the most important factors and issues of the functioning of the real sector of the economy, the social sphere, and foreign economic activity in the conditions of uncertainty in the oil and foreign exchange markets, as well as the implementation of quarantine and restrictive measures due to the propagation of the coronavirus infection. There is a decrease in investment in Amur Oblast, Sakhalin Oblast, Primorsky Krai, and the Republic of Sakha (Yakutia), which are the main 'investment-intensive' regions of the Far Eastern Federal District. There is still a significant industry asymmetry when it comes to attracting foreign direct investment, most of which is concentrated in the exploration and production of fuel and energy resources. The negative impact of macroeconomic shocks has led to a decrease in the volume of production in the industrial complex of the macroregion, especially affecting mechanical engineering, oil refining, and production of construction materials in Primorsky Krai and Khabarovsk Krai. The failure to implement the plans for the development of the railway infrastructure in the context of the growth of cargo flows to the seaports of the Far Eastern basin led to restrictions on cargo transportation. The reduction in the real monetary income of people in most regions of the Far Eastern Federal District is becoming a factor in reducing the attractiveness of the Far East as the high income area. The population of the macroregion has continued to decline not only due to migration outflow, but also due to natural population decline as a result of both factors of objective decline in the birth rate and the social and economic consequences of the pandemic.

Keywords: monitoring, GRP, industrial production, investment, inflation, labor market, standard of living, foreign trade, foreign investment, Far Eastern Federal District

For citation: Prokapalo O.M., Bardal A.B., Isaev A.G., Mazitova M.G., Suslov D.V. Economic Situation in the Far Eastern Federal District in 2020. Prostranstvennaya Ekonomika = Spatial Economics, 2021, no. 2, pp. 81-126. https://dx.doi.org/10.14530/se.2021.2.081-126 (In Russian). 
№ 22021

\section{МАКРОЭКОНОМИЧЕСКАЯ ДИНАМИКА}

В 2020 г. национальная экономика столкнулась с серьезными трудностями, вызванными негативными последствиями на нефтяном и валютном рынках, а также введением карантинных и ограничительных мер (социальное дистанцирование, изоляция) в связи с распространением коронавирусной инфекции. Кризисные шоки (гуманитарные, социальные, экономические, финансовые), распространяясь неравномерно по регионам, повлияли на деятельность целого ряда отраслей и секторов экономики (Аганбегян, 2020; Минакир, 2020). Частичная остановка или фактическое прекращение деятельности предприятий стало причиной снижения объемов выпуска и доходов населения, закрытие границ ведущих стран и экономических группировок привело к разрыву привычных хозяйственных связей и, как следствие, сокращению внешнеэкономического оборота, повышению цен на товары и продукты питания, дефициту рабочей силы. В результате в 2020 г. ВВП России уменьшился на 3,1\%, инвестиции - на 1,4\%, реальные денежные доходы населения - на 3\% (Социально-экономическое..., 2021).

На региональную экономическую систему оказывают влияние разнообразные шоки, которые сочетают в себе национальный экзогенный шок, промышленные шоки, которые могут сопровождаться другими шоками, возникающими в различных сферах экономики региона. Эти шоки могут усугубляться либо нивелироваться специфическими особенностями региональной социально-экономической системы (Михеева, 2021). Реакция региональных экономик на вызовы кризиса в условиях распространения коронавирусной инфекции может определяться как текущими неблагоприятными обстоятельствами, так и степенью оптимальности сложившейся структуры экономики. С ухудшением экономической конъюнктуры и сложностями выхода из кризиса столкнулись предприятия, предлагающие востребованные на рынке товары и услуги и вынужденно приостановившие свою деятельность. Однако их положение более благоприятно по сравнению с компаниями тех видов деятельности, в которых проблемы были еще до коронавируса (Кузнецова, 2020).

Реакцией экономики ДФО на действие разнообразных шоков стало снижение деловой активности. В 2020 г. ВРП округа, по экспертным оценкам, сократился и составил 97,7\%. Для отдельных отраслей экономики ДФО 2020 г. ознаменовался сменой амплитуды отклонения параметров регионального развития относительно среднероссийского уровня ${ }^{1}$. Если в 2018

${ }^{1}$ В целом ряде прежних исследований (Тихоокеанская..., 2010; Прокапало и др., 2020) было показано, что различия между динамикой экономических показателей РФ и ДФО обусловлены особенностями отраслевой структуры. 
2019 гг. темп роста промышленного производства ДФО значительно превышал общероссийские значения, то в 2020 г. снижение производства составило 4,1\% против 2,9\% в среднем по РФ (табл. 1).

\section{Динамика основных показателей развития экономики РФ и ДФО, \% к предыдущему году}

Таблица 1

Table 1

Key economic indicators, Russia and the Far Eastern Federal District, \% to previous year

\begin{tabular}{l|c|c|c|c|c|c}
\hline \multirow{2}{*}{\multicolumn{1}{c|}{ Показатель }} & \multicolumn{2}{|c|}{2019} & \multicolumn{2}{c|}{2020} & \multicolumn{2}{c}{$\begin{array}{c}\text { Справочно } \\
2020 / 2018\end{array}$} \\
\cline { 2 - 8 } & РФ & ДФО & РФ & ДФО & РФ & ДФО \\
\hline $\begin{array}{l}\text { Валовой внутренний (региональный) } \\
\text { продукт }\end{array}$ & 101,6 & 103,0 & 96,9 & $97,3^{1}$ & 98,4 & 100,2 \\
\hline Промышленное производство & 103,3 & 106,6 & 97,1 & 95,9 & 100,3 & 102,2 \\
\hline Инвестиции в основной капитал & 101,7 & 103,3 & 98,6 & 87,4 & 100,3 & 90,3 \\
\hline Экспорт товаров & 94,4 & 102,1 & 79,3 & 83,6 & 74,7 & 85,3 \\
\hline Импорт товаров & 102,4 & 133,4 & 94,7 & 96,1 & 97,0 & 128,2 \\
\hline Строительство & 102,1 & 130,6 & 100,1 & 91,4 & 102,2 & 119,4 \\
\hline $\begin{array}{l}\text { Индекс потребительских цен на товары } \\
\text { и услуги }\end{array}$ & 103,0 & 103,9 & 104,9 & 105,0 & 108,0 & 109,1 \\
\hline Реальные денежные доходы населения & 101,7 & 101,9 & 97,0 & 97,6 & 98,6 & 99,4 \\
\hline
\end{tabular}

Примечание: ${ }^{1}$ - оценка; ${ }^{2}$ - агрегированный индекс производства по видам экономической деятельности «Добыча полезных ископаемых», «Обрабатывающие производства», «Обеспечение электрической энергией, газом и паром; кондиционирование воздуха», «Водоснабжение; водоотведение, организация сбора и утилизации отходов, деятельность по ликвидации загрязнений».

Источники: Федеральная служба государственной статистики. 2021. URL: https://rosstat. gov.ru (дата обращения: январь 2021); Регионы..., 2020; Социально-экономическое..., 2020; Информация..., 2021.

Начальный этап спада промышленного производства в ДФО был зафиксирован во II квартале 2020 г., достигнув своего максимума к концу августа (минус 5\%) по сравнению с аналогичным периодом 2019 г. Основной компонентой сокращения общего объема промышленности выступают обрабатывающие производства (минус 8,3\%). В добывающих отраслях ДФО спад производства составил 3,6\%, на фоне значительного (минус 7\%) снижения в среднем по РФ. Тем не менее, по оперативной информации, в 2020 г. за макрорегионом сохраняется значительная роль в общероссийском производстве отдельных видов продукции: вылов морской рыбы - более 90\%, добыча угля - 19\% (2019 г. - 17\%), производство необработанных лесоматериалов $-9,4 \%(2019 \text { г. }-10,3 \%)^{1}$.

1 Производство основных видов продукции в натуральном выражении с 2017 г. (оперативные данные в соответствии с ОКПД2) / ЕМИСС. 2021. URL: https://fedstat.ru/indicator/57783 (дата обращения: апрель 2021). 
В 2020 г. в ДФО отмечен резкий спад (на 12,6\%) инвестиционной активности. Существенное влияние на динамику инвестиций оказало неблагоприятное сочетание таких факторов функционирования экономики, как сжатие внутреннего рынка, падение курса рубля, финансирование неотложных мер в сфере здравоохранения и сопряженных видах экономической деятельности. Под воздействием карантинных ограничений в III квартале инвестиции в основной капитал упали на 15,3\%. Такого глубокого снижения инвестиций в основной капитал не наблюдалось с 2013 г. В результате доля ДФО в общем объеме инвестиций снизилась и составила 7,7\% против 8,6\% в 2019 г. В шести дальневосточных субъектах РФ отмечено сокращение инвестиций, особенно сильное в Республике Саха (Якутия) (минус 51,6\%).

Снижение инвестиционной активности повлекло за собой сокращение объемов производства в строительной отрасли ДФО. По итогам 2020 г. снижение производства составило 8,6\% к уровню 2019 г. Наиболее резкое снижение объемов строительства было в первой половине 2020 г., когда глубина спада увеличилась с 18,7\% (январь) до 23,6\% (апрель). В сфере жилищного строительства, вопреки первоначальным опасениям, глубина кризиса оказалась небольшой - лишь на 0,5\% ниже уровня 2019 г. Это можно объяснить как мягкими санитарно-эпидемиологическими и административными ограничениями в строительстве, так и действиями правительства, направленными на поддержание потенциала строительного комплекса как одного из условий восстановления экономики и стимулирования рынка недвижимости.

Рецессия мировой экономики негативно повлияла на внешнюю торговлю. Стоимостной объем экспорта составил 83,6\% из-за снижения контрактных цен практически на все экспортные товарные группы, а также снижения мирового спроса на товары и услуги. Снижение импорта $(96,1 \%)$ связано с введением ограничительных мер в странах-партнерах, преимущественно в Китае.

Неопределенность развития ситуации в экономике, меры социального дистанцирования и изоляции, усиление тенденции к снижению реальных доходов оказывают влияние на потребительское поведение населения. Оборот розничной торговли по итогам 2020 г. составил 97,5\% к показателю предыдущего года, при значительном сокращении непродовольственных товаров до 94,3\% и сохранении на уровне 2019 г. оборота продовольственных товаров - 100,3\%. Фиксировались критически низкие показатели деятельности в секторах гостиничного, ресторанного, туристического, досугово-развлекательного бизнеса, бытовых услуг. По итогам 2020 г. объем платных услуг населению в ДФО составил $82,7 \%$, в том числе туристиче- 
ских - 49,2\%, гостиничных - 59,7\%, транспортных - 70,2\%, санаторно-курортных - 48,7\%, культурных - 48,9\%, спортивно-оздоровительных - 67,6\% относительно показателей 2019 г. $^{1}$

\section{ПРОМЫШЛЕННОЕ ПРОИЗВОДСТВО В ДФО В 2020 г.}

2020-й стал годом глубокой экономической рецессии, вызванной пандемией COVID-19. Ограничения, связанные с временным прекращением деятельности, коснулись и сектора промышленности. Помимо временной остановки производственной деятельности (за исключением ряда экономически важных видов деятельности) весной 2020 г., на некоторых секторах промышленности до сих пор сказываются продолжающиеся ограничения на ввоз иностранной рабочей силы. Промышленность ДФО в 2020 г. показала сокращение выпуска на 4,1\% по отношению к предыдущему году. Рост промышленного производства зафиксирован лишь в двух субъектах РФ Республике Бурятия $(107,4 \%)$ и Магаданской области $(105,6 \%)$. Снижение уровня промышленного производства в Хабаровском крае составило менее 1\%. В наихудшем положении оказался Приморский край, где обвал выпуска промышленной продукции составил 20,6\%. В каждом из остальных дальневосточных субъектов РФ падение производства не превысило 6\%.

В структуре промышленного производства ДФО по объемам отгруженной продукции собственного производства на добычу полезных ископаемых в 2020 г. пришлось 54,6\%, на обрабатывающие производства - 34\% и на остальные виды деятельности - 11,4\%. Добыча полезных ископаемых в округе сократилась на 7\%, главным образом, из-за сокращения добычи в Республике Саха (Якутия) (на 5,3\%) и Сахалинской области (на 3,8\%). На эти два субъекта РФ пришлось 77,4\% от всего объема отгруженной продукции добывающей промышленности ДФО. В четырех дальневосточных субъектах РФ, напротив, отмечен рост добычи: в Хабаровском крае - на 0,6\%, в Магаданской области - на 3,8\%, в Камчатском крае - на 9,2\%, в Республике Бурятия - на 15,7\%.

Высокие темпы прироста объемов производства сырой нефти и природного газа сохранились в Республике Саха (Якутия) - 113,8\%. Сахалинская область, напротив, сократила объемы добычи на 4,1\%. Добыча угля показала рост лишь в Хабаровском крае $(120,6 \%)$ и Сахалинской области $(105,8 \%)$, тогда как остальные угледобывающие регионы снизили объемы угледобычи: Забайкальский край - на 9,3\%, Приморский край - на 7,4\%, Республика Саха (Якутия) - на 8\%. Рост добычи металлических руд в отчетном году

${ }^{1}$ Объем платных услуг населению / ЕМИСС. 2020. URL: https://fedstat.ru/indicator/57788\# (дата обращения: март 2021). 
наблюдался лишь в Камчатском крае (111,4\%), Республике Саха (Якутия) (104,6\%), Сахалинской области (104\%) и Магаданской области (102,8\%).

Обрабатывающая промышленность не смогла удержать позиции предшествующего года - общее падение выпуска составило 8,3\%. Основные центры обрабатывающей промышленности ДФО, Хабаровский и Приморский края, снизили свои объемы выпуска. Если в Хабаровском крае сокращение составило незначительные 1,8\%, то в Приморском крае снижение было существенным - на 28,3\%. Рост выпуска отмечен в Республике Бурятия (на $6,8 \%$ ), Забайкальском крае (на 6,1\%) и Магаданской области (на 139,7\%).

Лесоперерабатывающий комплекс ДФО существенно снизил объемы производства в отчетном году за счет сокращения переработки древесины в Приморском (на 18,5\%) и Хабаровском (на 20,9\%) краях (табл. 2). На эти два субъекта РФ приходится более 90\% объемов отгруженной продукции деревопереработки ДФО. Лишь в Республике Саха (Якутия), занимающей весьма незначительную долю в территориальной структуре по данному виду деятельности, в 2020 г. наблюдался рост (134\%).

\section{Индексы промышленного производства ряда видов деятельности}

Таблица 2 обрабатывающей промышленности ДФО (2020 г. в \% к 2019 г.)

Table 2

Indices of industrial production by type of economic activity (in processing industry), the Far Eastern Federal District, 2020 as to 2019, in \%

\begin{tabular}{l|c|c|c}
\hline \multicolumn{1}{c|}{ Территория } & $\begin{array}{c}\text { Обработка древесины } \\
\text { и производство } \\
\text { изделий из дерева }\end{array}$ & $\begin{array}{c}\text { Производство } \\
\text { пищевых } \\
\text { продуктов }\end{array}$ & $\begin{array}{c}\text { Производство прочей } \\
\text { неметаллической } \\
\text { минеральной } \\
\text { продукции }\end{array}$ \\
\hline Республика Бурятия & 98,4 & 101,4 & 72 \\
\hline Республика Саха (Якутия) & 134 & 93,3 & 84,9 \\
\hline Забайкальский край & 86,2 & 99,1 & 70,1 \\
\hline Камчатский край & 80,5 & 91,3 & 77,9 \\
\hline Приморский край & 81,5 & 96,4 & 99,3 \\
\hline Хабаровский край & 79,1 & 109,8 & 71,5 \\
\hline Амурская область & 95,8 & 97,8 & 73,3 \\
\hline Магаданская область & 86,3 & 99,3 & 156,8 \\
\hline Сахалинская область & 95 & 106,8 & 75,2 \\
\hline ЕАО & 87,7 & 168,4 & - \\
\hline ЧАО & - & 25,1 & \\
\hline
\end{tabular}

Источник: составлено по: Производство основных видов продукции в натуральном выражении с 2017 г. (оперативные данные в соответствии с ОКПД2) / ЕМИСС. 2021. URL: https:// fedstat.ru/indicator/57783 (дата обращения: апрель 2021).

Значительный, более чем полуторакратный, рост производства пищевой промышленности отмечен в Еврейской автономной области (168,4\%). Кро- 
ме того, положительная динамика по итогам 2020 г. зафиксирована в Хабаровском крае $(109,8 \%)$, Сахалинской области $(106,8 \%)$ и Республике Бурятия (101,4\%). Обвальное сокращение производства пищевых продуктов испытал Чукотский автономный округ, где производство пищевых продуктов является единственным сектором обрабатывающей промышленности. Уровень производства зафиксирован на уровне всего 25,1\% от показателя 2019 г. На 8,7\% сократился выпуск пищевых продуктов в Камчатском крае. Во всех прочих регионах ДФО сокращение выпуска по данному виду деятельности варьировалось в интервале от 1 до 7\%.

Основными производителями строительных материалов в ДФО являются Приморский край, Амурская область, Еврейская автономная область и Республика Саха (Якутия), где расположены дальневосточные цементные заводы. Лишь Приморскому краю удалось поддержать объемы выпуска строительных материалов почти на уровне 2019 г. (падение составило чуть менее 1\%). В остальных регионах ДФО падение выпуска оказалось куда более существенным. Совокупные производственные мощности «Спасскцемента» (Приморский край), «Теплоозерскцемента» (Еврейская автономная область) и «Якутцемента» составляют 4,2 млн т в год, а общее потребление цемента в ДФО в 2019 г. - примерно 2,5 млн т. Средняя загрузка производств составляет 60\%, а мощности «Теплоозерскцемента» загружены менее чем на 50\%. В Еврейской автономной области сокращение выпуска по виду деятельности «производство прочей неметаллической минеральной продукции» составило 24,8\%. Амурская область сократила производство на 28,5\%, а Республика Саха (Якутия) - на 15,1\%.

Производство нефтепродуктов осуществляется в Хабаровском крае, где расположены два дальневосточных нефтеперерабатывающих завода. В 2020 г. отмечено снижение выпуска продукции нефтепереработки в Хабаровском крае на 17,9\%. Здесь не в последнюю очередь сказалось временное сокращение потребительского спроса на топливо во время апрельского режима самоизоляции.

Единственный на Дальнем Востоке металлургический завод «Амурсталь» (г. Комсомольск-на-Амуре) также сократил выпуск в отчетном году производство металлургической продукции в Хабаровском крае снизилось на $9,9 \%$.

Машиностроительные производства имеют значительные доли в структуре промышленности в Приморском и Хабаровском краях, в Республике Бурятия и (в меньшей степени) в Амурской области. Производство машин и оборудования существенно увеличилось в Амурской области $(175,1 \%)$ и Приморском крае $(121,5 \%)$, но заметно снизилось в Хабаровском крае - до 86,5\%. Производство автотранспортных средств в Приморском крае сохра- 
нилось практически на уровне 2019 г. (сокращение составило менее 1\%). Производство прочих транспортных средств в Хабаровском крае возросло на 11,9\%. В данную группировку включаются, главным образом, авиа- и судостроительные предприятия, относящиеся в основном к сектору ВПК и гражданского авиастроения. В 2020 г. в Комсомольске-на-Амуре было построено 11 гражданских самолетов «Суперджет-100», что на 7 машин меньше, чем в 2019 г. В Приморском крае наблюдался резкий обвал выпуска по данному виду деятельности - уровень производства 2020 г. составил всего 38\% от показателя 2019 г. В производстве электрического оборудования наблюдалась схожая картина. Если в Хабаровском крае отмечен рост выпуска до 114,5\%, то в Приморском крае - резкое сокращение выпуска на $59,5 \%$.

\section{СЕЛЬСКОЕ ХОЗЯЙСТВО}

На объемы производства и видовой состав сельскохозяйственной продукции на Дальнем Востоке оказывают влияние природно-климатические, географические, инфраструктурные особенности (Асеева и др., 2020; Сухомиров, 2015). В 2020 г. дополнительным сдерживающим фактором выступили ограничительные меры, связанные с пандемией (Терновский, Шагайда, 2021). Доля ДФО в общероссийском объеме производства продукции сельского хозяйства невысока и составляет всего 3,4\% (2020 г.). Несмотря на ограничительные факторы в условиях пандемии, производство продукции сельского хозяйства в ДФО увеличилось на 2,4\% по сравнению с 2019 г. Рост производства был отмечен во всех регионах ДФО, кроме слабоотрицательного снижения в Забайкальском крае на 1\% и нулевого роста в Республике Бурятия.

Совокупный рост производства объемов в сельском хозяйстве обеспечен как увеличением выпуска продукции растениеводства $(102,8 \%)$, так и слабоположительным ростом продукции животноводства (101,9\%). Под урожай 2020 г. в хозяйствах всех категорий ${ }^{1}$ было засеяно 2155,4 тыс. га посевной площади, что на 6,3\% меньше 2019 г. Основные посевные площади (1243,3 тыс. га) занимает соя. Зерновыми и зернобобовыми культурами было засеяно 531,1 тыс. га, картофелем - 75,0, овощами - 18,0, кормовыми культурами - 256,4 тыс. га. Площади сои уменьшились по сравнению с предыдущим годом на 8,6\%, зерновых и зернобобовых культур - на 2,2\%, картофеля - на 6,3\%, овощей - на 9,1\%, кормовых культур - на 5,3\%. Оперативные данные свидетельствуют о том, что сельскохозяйственным орга-

\footnotetext{
${ }^{1}$ Сельскохозяйственные организации; крестьянские (фермерские) хозяйства и индивидуальные предприниматели; хозяйства населения.
} 
низациям труднее справляться с возникающими вызовами и угрозами. Так, в сельхозорганизациях снижение посевных площадей сои составило 11,4\%, зерновых и зернобобовых культур - 4,5\% (в крестьянских (фермерских) хозяйствах и у индивидуальных предпринимателей - рост $3,4 \%$ ), овощей $33,1 \%$ (в крестьянских (фермерских) хозяйствах и у индивидуальных предпринимателей - снижение 6,5\%).

ДФО является одним из основных (наряду с Центральным федеральным округом) регионом РФ по производству соевых бобов. На долю ДФО приходится 34\% валового сбора соевых бобов ${ }^{1}$. В 2020 г., после неблагоприятного по климатическим условиям предыдущего года, было собрано 1450,3 тыс. т сои (рост 7,6\%) при урожайности 13,1 ц/га (в среднем по РФ - 15,9 ц/га).

Положительная динамика увеличения объемов также наблюдалась в производстве моркови (109\%), свеклы (103,1\%). Достаточно стабильным оставалось производство картофеля (100,8\%). Сократилось производство овощей (на $1,1 \%)$ и зерна $(11,2 \%)$.

Природно-климатические условия и наличие водных ресурсов позволяют в ДФО, преимущественно в Приморском крае, заниматься рисоводством (Сухомиров, 2018). Приморский рис обладает уникальными вкусовыми качествами, в связи с чем рисоводство можно рассматривать весьма перспективной отраслью. Но в настоящее время, из-за отсутствия финансовых ресурсов на проведение производственных и технологических мероприятий, ситуация в рисоводстве остается сложной. В 2020 г. отмечено снижение посевных площадей риса на 25,5\% (до 8,4 тыс. га). Увеличение урожайности до 26,8 ц/га (2019 г. - 23,0 ц/га) не смогло нивелировать значительного снижения посевов риса, что стало причиной сокращения валового сбора на 11,6\% (до 21,4 тыс. т).

В сельскохозяйственных организациях выращивается основной объем зерновых культур $(75,9 \%)$ и сои $(65,8 \%)$, а в хозяйствах населения сосредоточено основное производство картофеля $(77,5 \%)$ и овощей $(57,6 \%)$. Крестьянскими (фермерскими) хозяйствами и индивидуальными предпринимателями в 2020 г. произведено 34\% сои от общего сбора в хозяйствах всех категорий, зерновых культур - 23,8\%, овощей - 20,3\%, картофеля $-12,4 \%$.

В животноводческом комплексе продолжают сохранятся тенденции стагнации со слабоположительными темпами роста. Наибольший рост отмечен в производстве свинины $(112,1 \%)$, что обусловлено реализацией инвестиционных проектов в этой сфере и расширением экспортных возможностей для российских поставщиков. Положительная динамика также наблюдалась в производстве яиц $(106,4 \%)$, скота и птицы на убой

${ }^{1}$ Бюллетени о состоянии сельского хозяйства / ФСГС. 2021. URL: https://rosstat.gov.ru/ compendium/document/13277 (дата обращения: февраль 2021). 
(102,7\%), достаточно стабильным оставалось производство молока (99,8\%). К ключевым факторам, определяющим положительную динамику в отечественном животноводстве, следует отнести активное использование аграриями мер государственной поддержки, формирование племенной базы и укрепление ветеринарной защиты ${ }^{1}$.

В 2020 г. в хозяйствах ДФО выросла продажа сельхозорганизациями основных продуктов сельского хозяйства (кроме сои и овощей). По оперативной информации, реализовано по всем каналам 377,3 тыс. т зерна (119\% к уровню 2019 г.), 14,2 тыс. т картофеля (114\%), 75,1 тыс. т мяса скота и птицы (110\%), 107,5 тыс. т молока (104,9\%), 946 млн штук яиц $(114,8 \%)$, 4,1 т меда (106,7\%), 10,3 тыс. т риса (в 3,4 раза), 436,0 тыс. т сои $(90,6 \%)$, 27,7 тыс. т овощей $(98,1 \%)^{2}$.

Одним из направлений наращивания производства сельскохозяйственной продукции является расширение сельскохозяйственных угодий за счет проведения мелиоративных и осушительных мероприятий. Так, в Якутии разрабатывается новая программа развития мелиорации, в которой будет предусмотрено проведение мероприятий на восстановление существующих объектов и вовлечение в оборот 90 тыс. га угодий. В Хабаровском крае на реализацию мелиоративных мероприятий предусмотрено около 79 млн руб., в том числе 66,4 млн - из федерального бюджета. Это позволит ввести в оборот около 4,2 тыс. га земель. В Приморском крае для проведения реанимационных работ по модернизации мелиоративной системы и расширению рисоводства разрабатывается стратегия развития отрасли, реализация мероприятий которой потребует большого объема финансирования, а сроки окупаемости, даже с учетом господдержки, составят 8-12 лет ${ }^{3}$.

\section{СТРОИТЕЛЬСТВО}

Влияние коронавирусных ограничений, связанных с приостановкой проектов, сокращением рабочих мест, несоблюдением договорных условий, изменением цен на материалы повлияли на работу строительной отрасли. Объем работ, выполненных по виду деятельности «строительство», в 2020 г.

${ }^{1}$ В 2020 г. увеличилось производство продукции животноводства / Министерство сельского хозяйства Российской Федерации. 2021. URL: https://mcx.gov.ru/press-service/news/v-2020godu-uvelichilos-proizvodstvo-produktsii-zhivotnovodstva/ (дата обращения: февраль 2021).

2 Бюллетени о состоянии сельского хозяйства / ФСГС. 2021. URL: https://rosstat.gov.ru/ compendium/document/13277 (дата обращения: февраль 2021).

${ }^{3}$ Бондаренко А., Гарднер Ю., Таюрский В. Раскованное земледелие // Российская газета. 2020. 30 июля. URL: https://rg.ru/2020/07/30/reg-dfo/na-dalnem-vostoke-hotiat-vernut-v-oborotdesiatki-tysiach-gektarov-selhozugodij.html (дата обращения: март 2021). 
в ДФО составил 807,5 млрд руб. (8,5\% от общероссийского объема строительства). На функционирование строительной отрасли негативное влияние оказывает, наряду со снижением финансирования, недостаточное количество строительных организаций, способных качественно и своевременно выполнять запланированные работы. Это стало причиной снижения производства - 91,4\% к уровню 2019 г. Снижение объема строительных работ было характерно для большинства регионов ДФО, кроме Забайкальского края (140,7\%), Магаданской и Амурской областей (119,5 и 111,3\% соответственно), ЕАО (108,5\%) и Республики Бурятия (106,9\%) (табл. 3).

Строительный комплекс ДФО в 2020 г.

Таблицьа 3

Table 3

Construction sector, the Far Eastern Federal District, 2020

\begin{tabular}{l|c|c|c|c}
\hline \multirow{2}{*}{ Территория } & \multicolumn{2}{|c|}{$\begin{array}{c}\text { Объем работ, выполненных } \\
\text { по виду деятельности } \\
\text { «строительство» }\end{array}$} & \multicolumn{2}{|c}{ Ввод жилья ${ }^{1}$} \\
\cline { 2 - 5 } & млрд руб. & к 2019,\% & тыс. ${ }^{2}$ & к 2019,\% \\
\hline РФ & 9497,8 & 100,1 & 80600 & 98,2 \\
\hline ДФО & 807,5 & 91,4 & 2500,2 & 99,5 \\
\hline Республика Бурятия & 30,4 & 106,9 & 275,8 & 102,8 \\
\hline Республика Саха (Якутия) & 101,2 & 50,8 & 500,8 & 89,1 \\
\hline Забайкальский край & 47,7 & 140,7 & 170,7 & 78,7 \\
\hline Камчатский край & 20,2 & 85,2 & 68,1 & 152,3 \\
\hline Приморский край & 110,6 & 98,9 & 645,5 & 115,4 \\
\hline Хабаровский край & 88,6 & 99,1 & 223,1 & 75,7 \\
\hline Амурская область & 291,3 & 111,3 & 155,7 & 76,0 \\
\hline Магаданская область & 27,8 & 119,5 & 9,0 & 121,1 \\
\hline Сахалинская область & 70,1 & 82,0 & 435,7 & 131,4 \\
\hline ЕАО & 11,9 & 108,5 & 14,1 & 60,5 \\
\hline ЧАО & 7,6 & 74,5 & 1,7 & 132,3 \\
\hline
\end{tabular}

Примечание: ${ }^{1}$ - с 2019 г. данные о жилищном строительстве приводятся с учетом жилых домов, построенных населением на земельных участках, предназначенных для ведения садоводства, которые ранее не учитывались. Изменения связаны с тем, что в полном объеме начали действовать нормы Федерального закона от 29.07.2017 № 217-Ф3 «О ведении гражданами садоводства и огородничества для собственных нужд и о внесении изменений в отдельные законодательные акты Российской Федерации».

Источник: Социально-экономическое положение..., 2021.

Значительный рост объема строительных работ в Забайкальском крае связан с вводом в эксплуатацию мощностей по производству колбасных и хлебобулочных изделий, предприятий общественного питания, реконструкцией автомобильных дорог. В Магаданской области рост производства связан с увеличением объемов ввода жилья. 
Ограничительные меры в связи с пандемией несущественно повлияли на активность жилищного строительства на территории ДФО. Сфера жилищного строительства выступила своеобразным «антикризисным якорем» для экономики. В 2020 г. было введено 2500,2 тыс. м² жилья, что лишь на 0,5\% ниже уровня 2019 г. Среди регионов ДФО кризисные явления, повлиявшие на снижение объемов жилищного строительства, были отмечены в Республике Саха (Якутия), Забайкальском и Хабаровском краях, Амурской области, но сильнее всего проявились в ЕАО (60,5\%). Лидером по объему наращивания строительства жилья стала Сахалинская область. В 2020 г. в области было введено на душу населения 0,9 м² жилья, что выше аналогичного показателя в среднем по РФ $\left(0,6 \mathrm{~m}^{2}\right)$ и ДФО $\left(0,3 \mathrm{M}^{2}\right)$. Одним из факторов, направленных на увеличение объемов жилищного строительства в ДФО, является реализация мероприятий в рамках программы «Дальневосточная ипотека».

В 2020 г. в ДФО индивидуальными застройщиками возведено 1191,2 тыс. м² общей площади жилых помещений, что на 8,2\% ниже 2019 г. Доля индивидуального жилищного строительства в целом по ДФО соответствует среднероссийским показателям (48\%) со значительной вариацией по регионам - от нулевого значения в ЧАО до 70-100\% в Республике Бурятия, Забайкальском крае, ЕАО. Потенциальный рост индивидуального жилищного строительства может быть связан как с развитием территорий опережающего развития, так и с действующей программой «Дальневосточный гектар».

Сдерживающим фактором в области расширения жилищного строительства является запаздывание с обустройством строительных площадок необходимой инфраструктурой. Для устранения существующих проблем реализуется программа «Стимул» ${ }^{1}$, в которой принимают участие Амурская область, Республика Бурятия, Республика Саха (Якутия), Хабаровский край. В 2021-2024 гг. на финансирование программы в ДФО выделено около 3,5 млрд руб., что позволит построить около 1,3 млн м² жилья².

На фоне снижения доходов населения отмечается повышение стоимости жилья. Средняя цена одного квадратного метра жилья на первичном рынке на конец 2020 г. в ДФО увеличилась на 24,1\% и составила 91,1 тыс. руб., что на 15,3\% выше, чем в среднем по РФ.

1 По федеральной программе «Стимул» нацпроекта «Жилье и городская среда» строительство инфраструктуры ведется на условиях софинансирования из федерального, областного и местного бюджетов.

${ }^{2}$ Вице-премьеры и руководство ДФО обсудили меры, направленные на увеличение объемов жилищного строительства / Министерство Российской Федерации по развитию Дальнего Востока и Арктики. 2021. 1 февраля. URL: https://minvr.gov.ru/press-center/news/31328/ (дата обращения: март 2021). 


\section{ТРАНСПОРТ}

Проявления последствий ограничений в связи с пандемией COVID-19 в грузовом и пассажирском сегментах транспортной системы ДФО в 2020 г. различались. Наиболее серьезные негативные эффекты были зафиксированы при организации пассажирских перевозок, что соответствует мировой и российской тенденциям. При этом динамика конкретных показателей транспортной работы определялась спецификой региона.

Так, наблюдалось менее существенное, чем в целом по России, снижение показателя объема перевозок воздушным транспортом: $38,4 \%$ в ДФО при 46\% в РФ. Меньшее падение перевозок подтверждает значимость воздушного транспорта для обеспечения мобильности населения в условиях значительной площади макрорегиона и слаборазвитой наземной транспортной сети центральных и северных районов. Период наибольшего падения был зафиксирован в апреле 2020 г., когда объем перевезенных воздушным транспортом Дальнего Востока пассажиров сократился на 76,6\% по сравнению с аналогичным периодом 2019 г. (рис. 1).

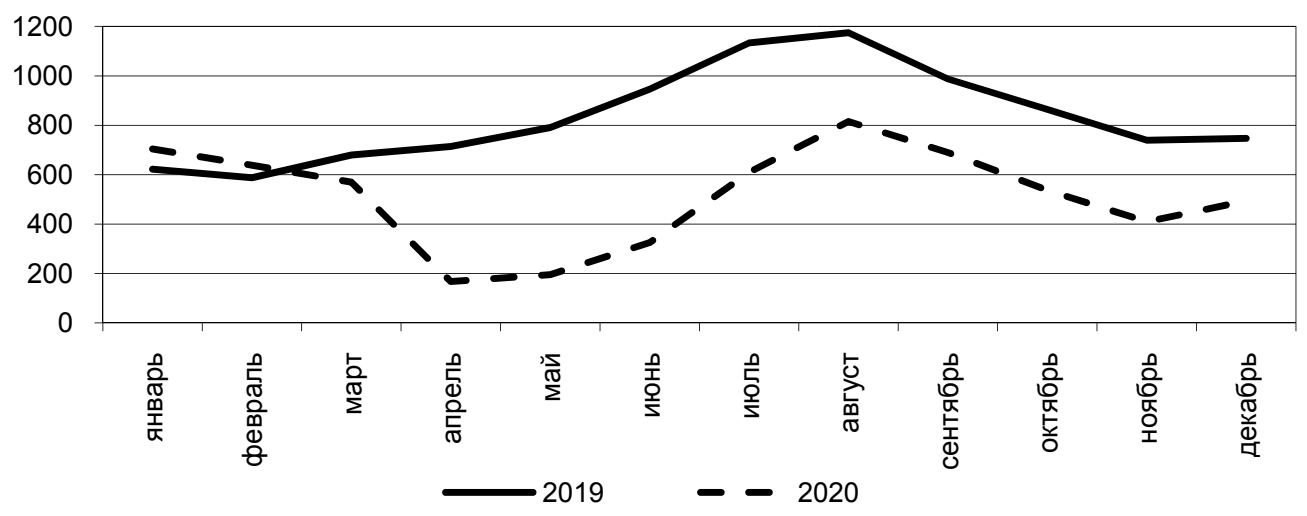

Puc. 1. Динамика пассажирских перевозок воздушным транспортом ДФО, тыс. чел.

Fig. 1. Dynamics of passenger air traffic in the Far Eastern Federal District, thousand people

Источник: составлено по: Федеральное агентство воздушного транспорта. 2020. URL: https://favt.gov.ru/ (дата обращения: апрель 2021).

Более низкий спад перевозок воздушным транспортом ДФО во время пандемии по сравнению с общероссийской динамикой определяется также наличием программ субсидирования федерального и регионального уровней и отличной от общероссийской структурой перевозок (более низкая доля международных воздушных линий, для которых вводились наиболее существенные ограничения в условиях закрытия границ). 
Последствия пандемии проявились и в снижении пассажирских перевозок железнодорожным транспортом ДФО, где наблюдался эффект, аналогичный воздушном транспорту: падение было меньшим по сравнению с общероссийским показателем. По итогам 2020 г. перевозки железнодорожным транспортом ДФО сократились на 16,2\% против 27,1\% по РФ ${ }^{1}$. Основной спад в макрорегионе для этого вида транспорта зафиксирован при организации перевозок в дальнем сообщении - на 29,4\%, тогда как сокращение пригородных перевозок составило лишь 6,2\%. По итогам 2020 г. отмечено общее снижение пассажирооборота на 34,5\%. Железнодорожный транспорт по-прежнему играл важную роль в обеспечении внутрирегиональной и межрегиональной мобильности населения Дальнего Востока.

В 2020 г. произошло также снижение пассажирских перевозок внутренним водным транспортом ДФО на 28,2\% ${ }^{2}$ (в целом по России снижение перевозок составило 31,8\%). Перевозки речным транспортом сократились в меньшей мере в тех субъектах РФ, где слабо развиты другие виды транспорта. При этом в 2020 г. значительно возросли перевозки внутренним водным транспортом Республики Бурятия (статистика фиксирует рост числа пассажиров в 24 раза по сравнению с 2019 г. - до 54 тыс. чел.), что может быть связано с ростом внутреннего туристического потока в условиях закрытия границ в период пандемии и с функционированием регулярных прогулочных маршрутов по озеру Байкал ${ }^{3}$.

В отличие от сегмента пассажирских перевозок в 2020 г. значительных негативных изменений в показателях грузовых перевозок ДФО не произошло, а для отдельных видов транспорта был отмечен рост перевозок. Перевозка грузов воздушным транспортом ДФО осталась практически на уровне 2019 г. (сокращение составило лишь 1,5\%), в то время как в целом по России зафиксировано падение показателя на $10,4 \%{ }^{4}$. Это еще раз подтверждает значимость воздушного транспорта, не имеющего альтернативы в северных и труднодоступных районах макрорегиона.

${ }^{1}$ Рассчитано по данным: Транспорт / ФСГС. 2020. URL: https://rosstat.gov.ru/folder/23455 (дата обращения: апрель 2021); Забайкальская железная дорога. 2021. URL: https://zabzd.rzd.ru/ (дата обращения: апрель 2021); Дальневосточная железная дорога. 2021. URL: https://dvzd.rzd. ru/ (дата обращения: апрель 2021); Восточно-Сибирская железная дорога. 2021. URL: https:// vszd.rzd.ru/ (дата обращения: апрель 2021); Акционерное общество «Акционерная компания „Железные дороги Якутии“»). 2021. URL: https://rw-y.ru/ (дата обращения: апрель 2021).

2 Объемы региональных и межрегиональных перевозок грузов и пассажиров внутренним водным транспортом / ЕМИСС. 2021. URL: https://fedstat.ru/indicator/35049 (дата обращения: апрель 2021).

${ }^{3}$ В Бурятии в 2020 году запустят новый прогулочный маршрут по Байкалу // PortNews. 2020. 18 февраля. URL: https://portnews.ru/news/291667/ (дата обращения: апрель 2021).

${ }^{4}$ Федеральное агентство воздушного транспорта. 2020. URL: https://favt.gov.ru/ (дата обращения: апрель 2021). 
Снижение перевозок грузов внутренним водным транспортом ДФО составило 7,3\% (при сокращении показателя на 8,3\% по РФ), что отражает важную роль речного транспорта, в том числе в обеспечении северного завоза.

В 2020 г. зафиксирован рост перевозок железнодорожным и морским транспортом Дальнего Востока. Так, объемы грузов, транспортируемых железнодорожным транспортом возросли на 2,3\% (оценка по погрузке), в то время как в целом по России объем грузовых перевозок по железным дорогам снизился на 2,7\%. Грузооборот железнодорожного транспорта ДФО увеличился на 3,2\% (снижение показателя по РФ составило 2,2\%). Рост по итогам 2020 г. произошел в большей степени за счет увеличившихся объемов перевозки угля (табл. 4).

Перевозка грузов железнодорожным транспортом в ДФО

Таблииа 4

Table 4

Cargo transportation by rail in the Far Eastern Federal District

\begin{tabular}{l|c|c|c}
\hline \multicolumn{1}{c|}{ Вид груза } & $\begin{array}{c}\text { Изменение объема } \\
2020 / 2019, \%\end{array}$ & $\begin{array}{c}\text { Удельный вес в общем } \\
\text { объеме перевозок } \\
\text { в 2020, \% }\end{array}$ & $\begin{array}{c}\text { Изменение доли } \\
2020 / 2019, \\
\text { п. п. }\end{array}$ \\
\hline Уголь & $+11,6$ & 40,4 & $+3,4$ \\
\hline Нефть и нефтепродукты & $-13,6$ & 13,8 & $-2,5$ \\
\hline Строительные грузы & 0,0 & 4,5 & $-0,1$ \\
\hline Лесные грузы & $-18,2$ & 4,9 & $-1,2$ \\
\hline Руда* & $+32,5$ & 7,2 & $+1,6$ \\
\hline Прочие & $-1,8$ & 29,4 & $-1,2$ \\
\hline
\end{tabular}

Примечание: * - цветные и черные металлы.

Источник: рассчитано по данным: Забайкальская железная дорога. 2021. URL: https://zabzd. rzd.ru/ (дата обращения: апрель 2021); Дальневосточная железная дорога. 2021. URL: https:// dvzd.rzd.ru/ (дата обращения: апрель 2021); Восточно-Сибирская железная дорога. 2021. URL: https://vszd.rzd.ru/ (дата обращения: апрель 2021); Акционерное общество «Акционерная компания „Железные дороги Якутии“». 2021. URL: https://rw-y.ru/ (дата обращения: апрель 2021).

В 2020 г. на 4,6\% возросла перевалка грузов через морские порты Дальневосточного бассейна. Общий объем перевалки составил 223,2 млн т, в то время как в целом по России этот показатель снизился на 2,3\% ${ }^{1}$. В структуре преобладают сухогрузы (в основном уголь) $-65,8 \%$.

В условиях продолжающегося роста объемов перевозок угля в направлении морских портов Тихоокеанского побережья грузоотправители сталкиваются с ограничениями пропускной способности железных дорог. Решение проблем развития инфраструктуры Восточного полигона должно проходить в рамках реализации проекта «Модернизация железнодорожной инфраструктуры Байкало-Амурской и Транссибирской железнодорожных

${ }^{1}$ Грузооборот морских портов России в 2020 году снизился на 2,3\% // PortNews. 2021. 18 января. URL: https://portnews.ru/news/307541/ (дата обращения: 12.04.2021). 
магистралей с развитием пропускных и провозных способностей», завершение первого этапа которого изначально планировалось в 2017 г. ${ }^{1}$, но срок был продлен до 2020 г. Второй этап модернизации предполагает рост пропускной способности железных дорог до 180 млн т к 2024 г. В 2019 г. был принят план по ускоренной модернизации Восточного полигона, согласно которому мероприятия по выделенным приоритетным участкам (212 ед.) должны быть завершены к 2023 г.

В течение 2020 г. в рамках проекта модернизации проведены работы на Байкало-Амурской и Транссибирской магистралях: на перегонах Курьян Тында, Олекма - 1945 км, Юктали - Талума, Кутыкан - Кувыкта, Юктали Тас-Юрях; на станциях Тында, Карымская, Чита-1, Чита-2, Екатеринославка, Забайкальск, Хилок, Белогорск-2 и др. В результате уложено более 100 км новых путей, стрелочных переводов, удлинены действующие пути, построены мосты и другие объекты инфраструктуры. Было открыто рабочее движение по второму Байкальскому тоннелю. Помимо этого в 2020 г. был сдан в эксплуатацию пункт технического обслуживания локомотивов на железнодорожной станции Забайкальск для магистральных и маневровых тепловозов. Поскольку эта станция является базовой для обслуживания пограничного пункта пропуска Забайкальск (РФ) - Маньчжурия (КНР), то обслуживаться будут в том числе тепловозы, использующиеся для внешнеторговых перевозок по железнодорожным путям с узкой колеей (шириной 1435 мм). Это позволит повысить эффективность работы данного пункта пропуска.

Однако невыполнение значительной части мероприятий первого и второго этапов проекта «Модернизация железнодорожной инфраструктуры Байкало-Амурской и Транссибирской железнодорожных магистралей с развитием пропускных и провозных способностей» в установленные сроки, а также перенос сроков выполнения отдельных мероприятий стали причиной возникновения проблем с пропускной способностью железных дорог ДФО.

В условиях дефицита пропускной способности Восточного полигона с 2020 г. изменены институциональные условия доступа грузоотправителей к инфраструктуре железнодорожного транспорта²: установлены приоритеты доступа на участки с ограничениями, предусмотрено двухэтапное квотирование компаний при перевозках угольных грузов.

${ }^{1}$ Об инвестиционном проекте «Модернизация железнодорожной инфраструктуры Байкало-Амурской и Транссибирской железнодорожных магистралей с развитием пропускных и провозных способностей: распоряжение Правительства Российской Федерации от 24 октября 2014 г. № 2116-p / Правительство России. 2014. URL: http://government.ru/docs/15414/ (дата обращения: апрель 2021).

${ }^{2}$ О внесении изменений в Правила недискриминационного доступа перевозчиков к инфраструктуре железнодорожного транспорта общего пользования: постановление Правительства Российской Федерации от 22 мая 2020 г. № 734. URL: http://docs.cntd.ru/document/564979863 (дата обращения: апрель 2021). 


\section{ИНВЕСТИЦИИ}

В 2020 г. отмечено резкое снижение инвестиционной активности в ДФО после непродолжительного оживления в 2017-2019 гг. Объем инвестиций в основной капитал в реальном выражении сократился на $12,6 \%$ по сравнению с 2019 г. Значительный спад инвестиций отмечен в Сахалинской области и Республике Саха (Якутия) - на 15,2 и 49,1\% соответственно, Приморском крае - на 9,5\%, Амурской области - на 6,1\% (Информация..., 2021). Тем не менее, в абсолютном объеме инвестиционных ресурсов ДФО совокупная доля Амурской и Сахалинской областей, Республики Саха (Якутия) остается высокой и составляет $50,2 \%$.

Существенный рост инвестиций (10-25\%) отмечен в Хабаровском, Забайкальском и Камчатском краях, ЧАО. Инвестиционная активность в Хабаровском крае связана с реализацией проектов в сфере энергетической и транспортной инфраструктуры, предприятий по производству пластиковых водосточных систем, деревообработки, торговли, строительства общеобразовательных учреждений и спортивных комплексов ${ }^{1}$. Рост инвестиций в Камчатском крае обеспечили проекты по строительству рыболовецких судов и рыбоперерабатывающих заводов, работы по созданию круглогодичного парка «Три вулкана», строительству спортивно-тренировочного центра у подножия Авачинского вулкана, реконструкции причальной инфраструктуры, закупки нового диагностического оборудования для учреждений здравоохранения и пр. ${ }^{2}$ В Забайкальском крае инвестиционно емкими являются проекты по строительству горно-металлургических комбинатов на медьсодержащем и золоторудном месторождениях, зернового железнодорожного терминала, освоению Талманской площади месторождения свинцово-цинковой руды ${ }^{3}$.

В общем объеме инвестиций лидирующими сферами деятельности (2019 г.) по-прежнему являются добыча полезных ископаемых (32,2\%), транспортировка и хранение $(23,9 \%)$, обрабатывающие производства $(16,8 \%)$.

Основную часть в финансировании капитальных вложений занимают собственные средства предприятий и организаций, доля которых постоян-

${ }^{1}$ О социально-экономическом развитии края / Министерство экономического развития Хабаровского края. URL: https://minec.khabkrai.ru/Deyatelnost/O-socialno-ekonomicheskomrazvitii-kraya (дата обращения: апрель 2021).

${ }^{2}$ Министерство экономического развития и торговли Камчатского края. 2021. URL: https:// kamgov.ru/minecon/monitoring/monitoring-socialno-ekonomiceskogo-razvitia-kamcatskogo-kraa (дата обращения: апрель 2021).

${ }^{3}$ Мониторинг социально-экономического положения за январь - декабрь 2020 года / Министерство экономического развития Забайкальского края. 2020. URL: https://minek.75.ru/ deyatel-nost/monitoring-social-no-ekonomicheskogo-polozheniya (дата обращения: март 2021). 
но растет и увеличилась в 2020 г. до 49,2\% (2018 г. - 46,2\%). Результатом 2020 г. стало резкое увеличение финансирования по статье «кредиты банков». По оперативной информации, их доля выросла практически в 2 раза и составила $18 \%$ общего объема инвестиций, а в Амурской области и Забайкальском крае этот показатель составлял 47,6 и 28,6\% соответственно. Рост банковских кредитов был связан, в том числе, с необходимостью компенсировать выпадающие денежные потоки как в период введения карантинных мероприятий, так и в период возобновления деловой активности (табл. 5).

Таблица 5

Структура инвестиций в основной капитал по источникам финансирования (без субъектов малого предпринимательства), \% к итогу

Structure of fixed capital investments by the source

Table 5 of financing (without SMEs) as \% of total

\begin{tabular}{l|c|c|c|c|c|c}
\hline \multirow{2}{*}{ Территория } & \multicolumn{3}{|c|}{2019} & \multicolumn{3}{c}{2020} \\
\cline { 2 - 7 } & $\begin{array}{c}\text { соб- } \\
\text { ственные } \\
\text { средства }\end{array}$ & $\begin{array}{c}\text { кредиты } \\
\text { банков }\end{array}$ & $\begin{array}{c}\text { бюд- } \\
\text { жетные } \\
\text { средства }\end{array}$ & $\begin{array}{c}\text { соб- } \\
\text { ственные } \\
\text { средства }\end{array}$ & $\begin{array}{c}\text { кредиты } \\
\text { банков }\end{array}$ & $\begin{array}{c}\text { бюд- } \\
\text { жетные } \\
\text { средства }\end{array}$ \\
\hline ДФО & 48,8 & 9,3 & 11,7 & 49,2 & 18,0 & 15,3 \\
\hline Республика Бурятия & 43,4 & 10,8 & 36,6 & 40,7 & 5,5 & 42,3 \\
\hline Республика Саха (Якутия) & 32,5 & 1,4 & 7,1 & 52,7 & 6,5 & 13,6 \\
\hline Забайкальский край & 40,5 & 17,9 & 13,1 & 36,6 & 28,6 & 16,2 \\
\hline Камчатский край & 55,3 & 2,7 & 36,9 & 57,1 & 6,9 & 31,0 \\
\hline Приморский край & 50,0 & 6,3 & 17,9 & 51,2 & 11,3 & 22,4 \\
\hline Хабаровский край & 42,7 & 21,3 & 12,8 & 56,3 & 7,3 & 12,4 \\
\hline Амурская область & 57,6 & 17,8 & 3,5 & 38,0 & 47,6 & 5,9 \\
\hline Магаданская область & 74,5 & 0,4 & 11,0 & 57,4 & 7,6 & 14,9 \\
\hline Сахалинская область & 70,9 & 5,3 & 14,5 & 65,4 & 2,4 & 18,2 \\
\hline ЕАО & 27,4 & $\ldots *$ & 16,8 & 43,3 & $\ldots *$ & 25,1 \\
\hline ЧАО & 31,2 & $\ldots *$ & 27,3 & 26,5 & $\ldots *$ & 15,9 \\
\hline
\end{tabular}

Примечание: ... вичных статистических данных, полученных от организаций, в соответствии с: Об официальном статистическом учете и системе государственной статистики в Российской Федерации (п. 5 ст. 4, ч. 1 ст. 9): федеральный закон от 29 ноября 2007 г. № 282-Ф3. URL: http://www.consultant. ru/document/cons_doc_LAW_72844/ (дата обращения: апрель 2021).

Источники: Регионы..., 2020; Инвестиции в основной капитал по источникам финансирования / ЕМИСС. 2020. URL: https://fedstat.ru/indicator/33644 (дата обращения: апрель 2020).

Одной из форм прямого участия государства в инвестиционной деятельности, осуществляемой в форме капитальных вложений, является федеральная адресная инвестиционная программа (ФАИП). В 2020 г. в ДФО в рамках этой программы было реализовано 163 мероприятия на общую сумму 
66,2 млрд руб. ${ }^{1}$ Наибольший объем инвестиционных ресурсов ФАИП был направлен на строительство объектов в Приморском крае (21,1 млрд руб.) и Республике Саха (Якутия) (15,7 млрд руб.). В Приморском крае были профинансированы строительство и реконструкция объектов морского транспорта, дорожного хозяйства, агропромышленного комплекса, образования, в Якутии - строительство спортивных сооружений, объектов воздушного транспорта и дорожного строительства.

В 2020 г. Правительством РФ были приняты решения, направленные на поддержку крупных инвестиционных проектов. Примером этого является принятый федеральный закон «О защите и поощрении капиталовложений в Российской Федерации»². Решения подобного рода всегда имеют региональные последствия в связи со значительным влиянием инвестиционных проектов на уровень социально-экономического развития территорий. На конец 2020 г. было заключено 25 соглашений о защите и поощрении капиталовложений, два из которых будут реализованы на Дальнем Востоке (Приморский край и Амурская область) (Кузнецова и др., 2021).

\section{ФИНАНСЫ}

Принятые жесткие меры в связи с распространением коронавирусной инфекции и вызванные этим ограничения экономической деятельности привели к общему снижению экономической активности и, как результат, к сокращению финансовых показателей. По оперативной информации, сальдированный финансовый результат в номинальном выражении (прибыль минус убыток) составил 800,1 млрд руб. и сократился по сравнению с 2019 г. на 12,1\%. Снижение прибыли (11,5-88,1\%) было отмечено в Камчатском и Хабаровском краях, Сахалинской области, ЕАО, с рекордным падением в Амурской области (табл. б). Убытки предприятий Амурской области составили 31,5 млрд руб., что является наихудшим показателем с 2008 г. Основная сумма убытков (96\%) приходится на предприятия по обеспечению электрической энергией, газом, паром и кондиционированию воздуха.

За 2020 г. в ДФО доля убыточных организаций по сравнению с 2019 г. увеличилась на 3,4 п. п. и составила $34,4 \%$. Значительный рост убыточных организаций (6,5-7,6 п. п.) отмечен в ЕАО, Амурской и Магаданской областях.

1 Федеральная адресная инвестиционная программа России / Департамент государственных целевых программ и капитальных вложений Минэкономразвития России. 2020. URL: https:/faip.economy.gov.ru/cgi/uis/faip.cgi/G1/region_list/2020 (дата обращения: март 2021).

2 О защите и поощрении капиталовложений в Российской Федерации: федеральный закон от 01 апреля 2020 г. № 69-Ф3. URL: http://www.kremlin.ru/acts/bank/45357/page/1 (дата обращения: апрель 2021). 
2021

Финансовые результаты деятельности организаций

Таблицุа 6

(без субъектов малого предпринимательства, банков,

страховых организаций и государственных / муниципальных организаций)

в январе - декабре 2020 г.

Table 6

Financial performance of organizations (without SMEs, banks, insurance companies, and state / municipal entities) in January - December 2020

\begin{tabular}{|c|c|c|c|c|c|}
\hline \multirow[b]{2}{*}{ Территория } & \multicolumn{2}{|c|}{$\begin{array}{c}\text { Сальдо прибылей (+) } \\
\text { и убытков (-) }\end{array}$} & \multicolumn{2}{|c|}{$\begin{array}{c}\text { Прибыль прибыльных } \\
\text { организаций }\end{array}$} & \multirow{2}{*}{$\begin{array}{c}\text { Удельный } \\
\text { вес убыточ- } \\
\text { ных пред- } \\
\text { приятий, \% }\end{array}$} \\
\hline & млн руб. & $\begin{array}{c}\text { к январю - } \\
\text { декабрю } \\
2019, \%\end{array}$ & млн руб. & $\begin{array}{c}\text { к январю - } \\
\text { декабрю } \\
2019, \%\end{array}$ & \\
\hline ДФО & 800104 & 87,9 & 1069124 & 102,7 & 34,4 \\
\hline Республика Бурятия & 26927 & 112,7 & 32427 & 114,5 & 35,8 \\
\hline Республика Саха (Якутия) & 228959 & 115,3 & 251826 & 112,6 & 32,9 \\
\hline Забайкальский край & 35095 & 106,1 & 53250 & 128,9 & 34,8 \\
\hline Камчатский край & 43495 & 88,5 & 45848 & 89,2 & 27,7 \\
\hline Приморский край & 129678 & 138,7 & 179388 & 147,0 & 32,6 \\
\hline Хабаровский край & 38271 & 84,3 & 87569 & 93,6 & 38,0 \\
\hline Амурская область & -31563 & - & 55188 & 137,3 & 34,9 \\
\hline Магаданская область & 80529 & 139,1 & 98358 & 166,5 & 32,9 \\
\hline Сахалинская область & 188799 & 53,7 & 199701 & 56,3 & 33,6 \\
\hline EAO & 183 & 11,9 & 1656 & 73,0 & 52,5 \\
\hline ЧАО & 59731 & 280,0 & 63913 & 261,6 & 32,0 \\
\hline
\end{tabular}

Источник: Информация..., 2021.

Предприятия добывающего сектора экономики стабильно сохраняют лидерство в наращивании объемов финансовых ресурсов, их доля в суммарном сальдированном показателе по ДФО составила 79\%. По-прежнему основной объем прибыли (более 55\%) обеспечили предприятия по добыче полезных ископаемых Республики Саха (Якутия) и Сахалинской области. Кроме этого, финансово устойчивыми были предприятия торговли, обрабатывающие производства, предприятия в сфере деятельности «транспортировка и хранение» (табл. 7).

На фоне положительной динамики финансовых показателей сохраняется высокая доля убыточных предприятий в ведущих отраслях экономики: в добывающем секторе Республики Бурятия, Хабаровском и Забайкальском краях, ЕАО (39-60\%), в строительном комплексе Хабаровского и Камчатского краев, ЕАО (44-70\%), на предприятиях транспортировки и хранения в Забайкальском крае, Амурской области, ЕАО (58-67\%). 


\section{Финансовые результаты организаций ДФО по основным видам экономической деятельности в январе - декабре 2020 г.}

Таблицุа 7

Financial performance of the Far Eastern Federal District organizations by type of economic activity, in January - December 2020

\begin{tabular}{l|c|c|c}
\hline \multicolumn{1}{c|}{ Вид деятельности } & $\begin{array}{c}\text { Сальдо } \\
\text { прибылей (+) } \\
\text { и убытков (-), } \\
\text { млн руб. }\end{array}$ & $\begin{array}{c}\text { Прибыль } \\
\text { организаций, } \\
\text { млн руб. }\end{array}$ & $\begin{array}{c}\text { Удельный } \\
\text { вес убыточ- } \\
\text { ных пред- } \\
\text { приятий, \% }\end{array}$ \\
\hline $\begin{array}{l}\text { Сельское, лесное хозяйство, охота, рыболов- } \\
\text { ство и рыбоводство }\end{array}$ & 49056,8 & 58352,3 & 28,6 \\
\hline Добыча полезных ископаемых & 632443,2 & 687546,4 & 38,5 \\
\hline Обрабатывающие производства & 36868,8 & 66055,4 & 31,8 \\
\hline $\begin{array}{l}\text { Обеспечение электрической энергией, газом и } \\
\text { паром; кондиционирование воздуха }\end{array}$ & $-111369,9$ & 15058,8 & 52,3 \\
\hline $\begin{array}{l}\text { Водоснабжение; водоотведение, организация } \\
\text { сбора и утилизации отходов, деятельность по } \\
\text { ликвидации загрязнений }\end{array}$ & $-914,8$ & 675,4 & 53,2 \\
\hline Строительство & $-6708,7$ & 9133,7 & 37,7 \\
\hline Транспортировка и хранение & 62731,7 & 70117,7 & 34,8 \\
\hline Торговля оптовая и розничная & 125944,8 & 129106,0 & 20,9 \\
\hline $\begin{array}{l}\text { Деятельность гостиниц и предприятий обще- } \\
\text { ственного питания }\end{array}$ & $-2465,1$ & 1073,5 & 52,3 \\
\hline $\begin{array}{l}\text { Деятельность в области информации } \\
\text { и связи }\end{array}$ & $-450,2$ & 600,2 & 30,6 \\
\hline
\end{tabular}

Источник: EMИCС. URL: https://fedstat.ru (дата обращения: апрель 2021).

Значительное снижение финансовых результатов оказало существенное влияние на динамику сбора налоговых платежей. Так, налог на прибыль организаций в целом по ДФО увеличился лишь на 4,6\%. При этом основной вклад в сохранение положительной динамики сбора налога внесли регионы, на территории которых реализуются крупные проекты по добыче полезных ископаемых, строительству, обслуживанию транспортной и газопроводной инфраструктуры (ЧАО, Амурская, Магаданская и Сахалинская области, Республика Саха (Якутия). Также в структуре налоговых доходов значительную долю занимает налог на совокупный доход физических лиц. Несмотря на частичную остановку производственного процесса в кризисный период, сохранилась положительная динамика поступления налоговых платежей. Так, в ДФО рост налога на совокупный доход увеличился на 5,7\% по сравнению с 2019 г. Рост показателя (в диапазоне 2-13\%) отмечен во всех регионах ДФО. 


\section{ИНФЛЯЦИЯ}

В 2020 г. на фоне замедления деловой активности отмечался рост уровня инфляции. Темп роста потребительских цен на товары и услуги в ДФО составил 5\% (2019 г. - 3,9\%) и приблизился к уровню 2016 г. Индекс цен на продовольственные товары составил 6,6\%, превысив на 2,3 п. п. уровень 2019 г. Изменение розничных цен на продовольствие происходило неравномерно: в большей степени увеличились цены на те продукты, в экспорте (зерно, подсолнечное масло) и импорте (овощи, фрукты) которых страна интегрирована в мировой рынок (Терновский, Шагайда, 2021). Рост продовольственных цен связан с неурожаем отдельных видов сельскохозяйственных культур, повышенным спросом на продукты питания из-за паники потребителей (стихийное накопление продовольствия), а также с «импортом инфляции» с мировых рынков продовольствия (Тринадцать..., 2020). Значительно увеличились цены на плодоовощную продукцию, макаронные изделия, крупы и бобовые, хлеб и хлебобулочные изделия. Лидерами роста цен на дальневосточном рынке стали сахар (+36\%) и подсолнечное масло $(+32,8 \%)$ (табл. 8$)$.

Темпы роста (снижения) потребительских цен по видам

Таблица 8 и группам товаров и платных услуг в ДФО в 2020 г., \% к декабрю 2019 г.

Table 8

Rate of increase in consumer prices by the kind and group of commodities and paid services in the Far Eastern Federal District, December 2020 against December 2019, in \%

\begin{tabular}{l|c|l|l|l|l}
\hline \multicolumn{2}{l|}{ Продовольственные товары } & \multicolumn{2}{l|}{ Непродовольственные товары } & \multicolumn{2}{l}{ Платные услуги населению } \\
\hline $\begin{array}{l}\text { Макаронные и крупя- } \\
\text { ные изделия }\end{array}$ & $+15,4$ & $\begin{array}{l}\text { Электротовары и дру- } \\
\text { гие бытовые приборы }\end{array}$ & $+4,3$ & $\begin{array}{l}\text { Жилищно-комму- } \\
\text { нальные }\end{array}$ & $+3,6$ \\
\hline Крупа и бобовые & $+17,8$ & Легковые автомобили & $+4,0$ & $\begin{array}{l}\text { Пассажирский } \\
\text { транспорт }\end{array}$ & $+4,9$ \\
\hline Сахар-песок & $+36,0$ & Бензин автомобильный & $+5,6$ & воздушный & $+6,2$ \\
\hline $\begin{array}{l}\text { Плодоовощная про- } \\
\text { дукция }\end{array}$ & $+18,0$ & $\begin{array}{l}\text { Строительные мате- } \\
\text { риалы }\end{array}$ & $+4,9$ & железнодорожный & $+0,8$ \\
\hline $\begin{array}{l}\text { Хлеб и хлебобулочные } \\
\text { изделия }\end{array}$ & $+7,2$ & Медикаменты & $+11,6$ & Внутренний туризм & $+4,0$ \\
\hline Масло подсолнечное & $+32,8$ & Одежда & $+1,2$ & Зарубежный туризм & $-1,2$ \\
\hline Масло сливочное & $+3,7$ & Трикотажные изделия & $+2,2$ & Связь & $+4,0$ \\
\hline $\begin{array}{l}\text { Молоко и молочная } \\
\text { продукция }\end{array}$ & $+4,2$ & Обувь & $+0,8$ & Медицина & $+5,0$ \\
\hline Мясо и птица & $+0,9$ & Табачные изделия & $+8,6$ & Образование & $+1,2$ \\
\hline Рыба и морепродукты & $+4,2$ & Ювелирные изделия & $+19,6$ & $\begin{array}{l}\text { Физическая культура } \\
\text { и спорт }\end{array}$ & $+2,5$ \\
\hline Яйцо & $+3,0$ & & & & \\
\hline Алкогольные напитки & $+4,1$ & & & & \\
\hline
\end{tabular}

Источник: Индексы потребительских цен на товары и услуги / EMИCC. 2020. URL: https:// fedstat.ru/indicator/31074 (дата обращения: апрель 2021). 
Минимальный рост цен на мясную продукцию можно объяснить снижением спроса в связи с ограничением режима работы заведений общественного питания и гостиничного бизнеса. Для сдерживания роста цен на социально значимые товары Правительством РФ в декабре 2020 г. было принято решение заморозить цены на сахар и подсолнечное масло. По оценкам экспертов, эта мера несущественно повлияет на ценовую динамику, поскольку была принята уже после значительного подорожания продукции (Божечкова, Трунин, 2021).

Непродовольственная инфляция выросла до 4,6\% и увеличилась на 1,7 п. п. по сравнению с 2019 г. Резкий ценовой скачок стоимости ювелирных изделий (19,6\%) связан с ростом цены на золото, падением курса рубля, ростом продаж за счет нереализованных заказов в период самоизоляции, желанием отдельных категорий населения инвестировать в покупку бриллиантов. Значительный прирост цен за счет ажиотажного покупательского спроса зафиксирован по категории «медикаменты» $(11,6 \%)$, что на 3,9 п. п. выше показателя 2019 г. Минимальный рост цен $(0,8-2,2 \%)$ наблюдался в сегменте верхней одежды и обуви.

Платные услуги населению подорожали на 3,4\% (2019 г. - 4,5\%), так как именно в этом секторе было значительное падение спроса в результате карантинных ограничений. При этом росли цены на перевозки воздушным транспортом, на медицинские услуги, но темпы роста были значительно ниже 2019 г. Напротив, в секторе зарубежного туризма наблюдалась дефляция $(-1,2 \%)$.

\section{ДОХОДЫ НАСЕЛЕНИЯ}

Нестандартные условия функционирования экономики при жестком регламентировании хозяйственной деятельности и социальной активности населения оказали существенное влияние на формирование доходов населения. В 2020 г. реальные денежные доходы населения в ДФО сократились на 2,4\% после двухлетнего слабоположительного роста. Снижение денежных доходов населения в реальном выражении наблюдалось во всех (кроме Камчатского края, Магаданской области и ЧАО) дальневосточных субъектах РФ (табл. 9). Дальний Восток теряет свою привлекательность в сфере высоких доходов населения. Если в 1995 г. превышение уровня среднедушевых денежных доходов населения на Дальнем Востоке над среднероссийским уровнем составляло примерно 26\% благодаря высоким номинальным доходам в районах Крайнего Севера (Найден, 2020), то в 2020 г. это превышение составило лишь 9\%. При этом в четырех дальневосточных субъектах РФ уровень денежных доходов был ниже среднероссийского (в Амурской области - 99\%, Республике Бурятия, Забайкальском крае и ЕАО - 72-78\%). 
Таблица 9

Динамика реальных денежных доходов населения, \% к предыдущему году

Table 9

Dinamic of real personal incomes, $\%$ of the previous year

\begin{tabular}{l|c|c|c|c}
\hline \multicolumn{1}{c|}{ Территория } & 2018 & 2019 & 2020 & $2020 / 2017$ \\
\hline РФ & 101,1 & 101,7 & 97,0 & 99,7 \\
\hline ДФО & 103,2 & 101,9 & 97,6 & 102,6 \\
\hline Республика Бурятия & 97,8 & 99,3 & 97,0 & 94,2 \\
\hline Республика Саха (Якутия) & 102,4 & 102,7 & 97,3 & 102,3 \\
\hline Забайкальский край & 102,1 & 101,9 & 98,6 & 102,6 \\
\hline Камчатский край & 105,1 & 103,9 & 100,1 & 109,3 \\
\hline Приморский край & 103,8 & 101,9 & 96,7 & 102,3 \\
\hline Хабаровский край & 101,5 & 100,7 & 96,2 & 98,3 \\
\hline Амурская область & 102,4 & 101,7 & 99,2 & 103,3 \\
\hline Магаданская область & 104,4 & 103,1 & 100,8 & 108,5 \\
\hline Сахалинская область & 104,7 & 105,6 & 97,9 & 108,2 \\
\hline ЕАО & 99,6 & 101,2 & 98,6 & 99,4 \\
\hline ЧАО & 104,3 & 101,5 & 105,5 & 111,7 \\
\hline
\end{tabular}

Источники: Регионы..., 2020; Информация..., 2021.

В структуре денежных доходов населения РФ основную долю занимают оплата труда (59\%) и социальные выплаты (21\%) 1 . По ДФО среднемесячная начисленная заработная плата работников составила 59,9 тыс. руб., в номинальном выражении на 5,4\% превысив уровень 2019 г. Рост номинальной заработной платы варьировал в диапазоне от 101,5\% (Хабаровский край) до $112,8 \%$ (ЧАО).

Соотношение оплаты труда по видам экономической деятельности оставалось в интервале длительных наблюдений. Традиционно номинальный уровень оплаты труда лидирует в добывающих отраслях (добыча полезных ископаемых, рыболовство), финансовой деятельности, в то время как общественный сектор (образование, здравоохранение, культура, коммунальная сфера) значительно отстает. Несмотря на санитарно-эпидемиологическую обстановку и строгие ограничения на экономическую и социальную деятельность, удалось сохранить положительную динамику повышения реальной заработной платы $(101,4 \%)$, но темп роста существенно уступал значениям 2018-2019 гг. (109,3 и 104,4\% соответственно). Положительные темпы роста в интервале $101,3 \%-110,7 \%$ отмечены в большинстве дальневосточных субъектов РФ на фоне снижения уровня реальной заработной платы в Сахалинской области $(99,9 \%)$ и Хабаровском крае $(97,7 \%)$.

${ }^{1}$ Объем и структура денежных доходов населения Российской Федерации по источникам поступления / ФСГС. 2020. URL: https://rosstat.gov.ru/folder/13397 (дата обращения: апрель 2021). 
На начало 2021 г. в целом по ДФО размер среднемесячной начисленной пенсии составил 17,4 тыс. руб. и в реальном выражении она увеличилась на 0,5\% по сравнению с 2019 г. Отрицательная динамика реальных пенсий в диапазоне 98,9-99,9\% отмечена в Амурской и Магаданской областях, ЕАО и Республике Бурятия.

В 2020 г. изменилась структура расходования денежных средств населения ДФО. Доля денежных средств, использованных на покупку непродовольственных товаров и оплату услуг, в январе - сентябре 2020 г. сократилась по сравнению с аналогичным периодом 2019 г. на 2,2 п. п. ${ }^{1}$ При этом в структуре расходов доля средств, используемых на покупку продуктов питания, увеличилась с 33,4\% (III кв. 2019 г.) до 35,8\% (III кв. 2020 г.).

\section{ДЕМОГРАФИЧЕСКАЯ СИТУАЦИЯ}

В настоящее время в Дальневосточном макрорегионе не преодолена негативная тенденция сокращения численности населения. На 1 января 2021 г., по оперативной информации, численность постоянного населения ДФО составила 8124,0 тыс. чел. и по сравнению с началом 2020 г. сократилась на 45,2 тыс. чел. И это является рекордным спадом за последние 10 лет. На снижение общего числа жителей региона негативное влияние оказывает сохранение высокой естественной убыли населения. В 2020 г. естественная убыль населения ДФО составила 22026 чел. и увеличилась по сравнению с 2019 г. в 2,4 раза. Особенностью 2020 г. является ускорение естественной убыли населения за счет снижения рождаемости и возросшего количества умерших. Так, соотношение количества умерших к родившимся в целом по ДФО увеличилось и составило 1,24 (в 2019 г. - 1,098). То есть, за год умерло в 1,2 раза больше людей, чем родилось. В Хабаровском и Приморском краях, ЕАО и Амурской области этот показатель варьировал в диапазоне 1,47-1,61. Положительный естественный прирост населения (но со снижающимися темпами роста) традиционно сохраняется лишь в Республике Бурятия, Республике Саха (Якутия) и ЧАО (табл. 10).

В ДФО, в условиях более молодого возрастного состава населения, а также менталитета жителей национальных республик и автономий, уровень рождаемости превышает среднероссийский. По итогам 2020 г. общий коэффициент рождаемости в ДФО составил $11,0 \%$ при среднероссийском уровне 9,8\% и варьировал по дальневосточным субъектам РФ в интервале от 9,4 до $13,3 \%$.

1 Доходы, расходы и потребление домашних хозяйств / ФСГС. 2020. URL: https://rosstat. gov.ru/compendium/document/13271 (дата обращения: апрель 2021). 
Динамика родившихся, умерших, естественного прироста

Таблица 10 населения в ДФО, чел.

Dynamics of newborn, deceased and natural population growth

Table 10 in Russia and the Far Eastern Federal District, people

\begin{tabular}{l|c|c|c|c|c|c}
\hline \multirow{2}{*}{ Территория } & \multicolumn{2}{|c|}{ Число родившихся } & \multicolumn{2}{c|}{ Число умерших } & \multicolumn{2}{c}{$\begin{array}{c}\text { Естественный } \\
\text { прирост (+), } \\
\text { убыль (-) }\end{array}$} \\
\cline { 2 - 8 } & 2019 & 2020 & 2019 & 2020 & 2019 & 2020 \\
\hline ДФО & 91045 & 90000 & 100002 & 112026 & -8957 & -22026 \\
\hline Республика Бурятия & 12524 & 12620 & 10886 & 11622 & +1638 & +998 \\
\hline Республика Саха (Якутия) & 12819 & 12957 & 7611 & 8956 & +5208 & +4001 \\
\hline Забайкальский край & 12560 & 12484 & 13168 & 14305 & -608 & -1821 \\
\hline Камчатский край & 3302 & 3240 & 3459 & 3962 & -157 & -722 \\
\hline Приморский край & 18232 & 18060 & 25730 & 28837 & -7498 & -10777 \\
\hline Хабаровский край & 14479 & 13739 & 17644 & 20254 & -3162 & -6515 \\
\hline Амурская область & 7919 & 7853 & 11088 & 12677 & -3169 & -4824 \\
\hline Магаданская область & 1308 & 1314 & 1625 & 1756 & -317 & -442 \\
\hline Сахалинская область & 5693 & 5591 & 6064 & 6645 & -371 & -1054 \\
\hline ЕАО & 1683 & 1605 & 2271 & 2490 & -588 & -885 \\
\hline ЧАО & 526 & 537 & 456 & 522 & +70 & +15 \\
\hline
\end{tabular}

Источник: Социально-экономическое..., 2021.

В 2020 г. суммарный коэффициент рождаемости в среднем по ДФО составил $1,7^{1}$ ребенка на одну женщину в репродуктивном возрасте, что на $1,8 \%$ выше уровня 2019 г. $(1,67)$ и на $13,3 \%$ выше среднероссийского значения $(1,5)$. Рост показателя отмечен во всех (кроме ЕАО) дальневосточных регионах. В 2020 г. лидерство по уровню суммарного коэффициента рождаемости сохранили Сахалинская область (1,97 ребенка на одну женщину в репродуктивном возрасте), Республика Бурятия $(1,95)$, Республика Саха (Якутия) $(1,86)$. Но значение показателя на уровне 2,1 и выше характеризует простое воспроизводство населения, когда каждое новое поколение по численности равно предыдущему. Поэтому даже при таком уровне показателя абсолютное число рождений каждый год будет сокращаться в связи с неблагоприятной возрастной структурой населения в результате снижения числа женщин репродуктивного возраста.

На фоне абсолютного роста числа умерших отмечено снижение младенческой смертности. В 2020 г. смертность детей до 1 года на 1000 рожденных живыми в ДФО составила 5 случаев. Это ниже аналогичного показателя

${ }^{1}$ Суммарный коэффициент рождаемости / ЕМИСС. 2021. URL: https://www.fedstat.ru/ indicator/31517 (дата обращения: апрель 2021). 
2019 г. на 12,3\% (5,7 случая), но выше среднероссийского значения на 11,1\% (4,5 случая). Максимальный уровень младенческой смертности не только в ДФО, но и в РФ зарегистрирован в ЧАО (15,1 случая).

Отмечено снижение ожидаемой продолжительности жизни в 2020 г. относительно 2019 г.: по России - с 73,3 до 71,5 года, по ДФО - с 70,2 до 69,2. В регионах ДФО ожидаемая продолжительность жизни при рождении варьирует от 65,8 лет (ЧАО) до 71,1 года (Республика Саха (Якутия) ${ }^{1}$.

По оценкам экспертов, в ближайшие годы сохранится негативный тренд естественной убыли населения как за счет факторов объективного снижения рождаемости, так и за счет социальных и экономических последствий пандемии (Хасанова, Зубаревич, 2021).

Из-за запретов и ограничений, вызванных пандемией коронавирусной инфекции, миграционная подвижность населения ДФО в 2020 г. составила 598,5 тыс. чел. и уменьшилась по сравнению с 2019 г. на 11\%. В результате миграционного обмена ДФО потерял 19925 чел. (2019 г. - 11731 чел.). В 2020 г. число мигрантов, прибывших в регионы ДФО, сократилось на 12,5\% по сравнению с 2019 г., в то время как число выбывших уменьшилось на 9,7\%. Отрицательное сальдо миграции было характерно для всех, кроме Республики Саха (Якутия), дальневосточных субъектов РФ (табл. 11).

Общие итоги миграции населения по территориям ДФО, чел.

Таблица 11

Table 11

Overall migration by the the Far Eastern Federal District territories, people

\begin{tabular}{l|c|c|c|c|c|c}
\hline \multirow{2}{*}{\multicolumn{1}{c|}{ Территория }} & \multicolumn{2}{c|}{ Число прибывших } & \multicolumn{2}{c|}{ Число выбывших } & \multicolumn{2}{c}{ Сальдо миграции } \\
\cline { 2 - 7 } & 2019 & 2020 & 2019 & 2020 & 2019 & 2020 \\
\hline ДФО & 330375 & 289323 & 342106 & 309248 & -11731 & -19925 \\
\hline Республика Бурятия & 45382 & 39850 & 44383 & 41200 & +999 & -1350 \\
\hline Республика Саха (Якутия) & 42449 & 47355 & 42766 & 41290 & -317 & +6065 \\
\hline Забайкальский край & 29068 & 24882 & 34587 & 28972 & -5519 & -4090 \\
\hline Камчатский край & 14190 & 13430 & 15779 & 13547 & -1589 & -117 \\
\hline Приморский край & 79949 & 64699 & 79888 & 70914 & +61 & -6215 \\
\hline Хабаровский край & 51069 & 39050 & 54130 & 46404 & -3061 & -7354 \\
\hline Амурская область & 29604 & 24956 & 29598 & 28099 & +6 & -3143 \\
\hline Магаданская область & 7915 & 6908 & 8664 & 7527 & -749 & -619 \\
\hline Сахалинская область & 20440 & 19953 & 21510 & 21400 & -1070 & -1447 \\
\hline ЕАО & 4281 & 3527 & 5319 & 4422 & -1038 & -895 \\
\hline ЧАО & 6028 & 4713 & 5482 & 5473 & +546 & -760 \\
\hline
\end{tabular}

Источник: Социально-экономическое..., 2021.

${ }^{1}$ Демография / ФСГС. 2021. URL: https://rosstat.gov.ru/folder/12781 (дата обращения: апрель 2021). 
Во всех субъектах РФ преобладают «внутренние» миграционные потоки, связанные со сменой места жительства в пределах России. Основной поток миграционных перемещений жителей ДФО направлен в южные, центральные, северо-западные регионы страны, обладающие конкурентными преимуществами качества и уровня жизни.

Тенденции положительного миграционного сальдо в ДФО за счет миграционного обмена со странами СНГ сохранялись и в 2020 г. Чаще всего труд иностранных граждан используется в строительстве, сельском хозяйстве, добыче полезных ископаемых, транспорте, торговле, сфере услуг. За счет миграционного обмена со странами СНГ численность населения ДФО в 2020 г. увеличилась на 4844 чел. (2019 г. - 11397 чел.).

В 2020 г. не удалось сохранить параметры положительного миграционного взаимодействия со странами дальнего зарубежья, отмеченного в 2019 г. По оперативной информации, в результате роста числа выбывших из макрорегиона сальдо миграционной убыли составило 3746 чел. против роста 2849 чел. в 2019 г. В абсолютном выражении отрицательный миграционный поток наблюдался в Хабаровском и Приморском краях (1463 и 1001 чел. соответственно), Амурской области (668 чел.).

Помимо Росстата, сведения об основных показателях миграционной ситуации в РФ публикует Главное управление по вопросам миграции Министерства внутренних дел РФ. Так, в 2020 г. на миграционный учет в ДФО было поставлено 631,6 тыс. иностранных граждан и лиц без гражданства (2019 г. - 1373,8 тыс. чел.). Из общего числа 96,8\% были зарегистрированы по месту пребывания, 3,2 \% - по месту жительства. Из общего числа поставленных на миграционный учет по месту пребывания первично (161,7 тыс. чел.) въехало в ДФО с целью работы 64,8\%, с целью туризма $15,4 \%$, с целью учебы - 2,1\%, с частными и иными целями $-17,7 \%{ }^{1}$.

\section{РЫНОК ТРУДА}

Реакцию рынка труда на пандемию можно охарактеризовать как гистерезис. Это такое свойство системы, когда ее крайние состояния характеризуются разными траекториями, то есть вход в отрицательный сценарий происходит по одной траектории, а выход из него - по другой. Применительно к рынку труда это означает, что под воздействием шока безработица увеличивается быстро, но сокращается медленно, и для этого требуются большие усилия (Буторина, 2020).

${ }^{1}$ Отдельные показатели миграционной ситуации в Российской Федерации за январь декабрь 2020 г. с распределением по регионам / Министерство внутренних дел Российской Федерации. 2021. URL: https:/мвд.pф/Deljatelnost/statistics/migracionnaya/item/22689602/ (дата обращения: апрель 2021). 
К концу 2020 г, после периода снижения безработицы, численность безработных ${ }^{1}$ составила 274,3 тыс. чел. и увеличилась на 7,9\% по сравнению с 2019 г. (табл. 12).

Таблица 12

Численность безработных в 2020 г. (по данным выборочного обследования рабочей силы)

Table 12

Number of unemployed in 2020 (according to a labor survey)

\begin{tabular}{l|c|c|c|c}
\hline \multicolumn{1}{c|}{ Территория } & $\begin{array}{c}\text { Безработные, } \\
\text { тыс. чел. }\end{array}$ & $\begin{array}{r}2020 / \\
2019, \%\end{array}$ & $\begin{array}{c}\text { Среднее время } \\
\text { поиска работы } \\
\text { безработными, } \\
\text { месяцев }\end{array}$ & $\begin{array}{c}\text { Доля ищущих работу } \\
\text { 12 месяцев и более } \\
\text { в общей численно- } \\
\text { сти безработных, \% }\end{array}$ \\
\hline ДФО & 274,3 & 107,9 & 7,3 & 26,4 \\
\hline Республика Бурятия & 45,0 & 112,9 & 7,0 & 25,0 \\
\hline Республика Саха (Якутия) & 37,0 & 107,5 & 6,4 & 16,5 \\
\hline Забайкальский край & 51,5 & 105,8 & 9,6 & 48,5 \\
\hline Камчатский край & 6,9 & 100,6 & 5,2 & 15,9 \\
\hline Приморский край & 54,7 & 106,1 & 7,3 & 18,4 \\
\hline Хабаровский край & 28,7 & 107,3 & 6,3 & 21,0 \\
\hline Амурская область & 24,0 & 109,9 & 7,1 & 17,5 \\
\hline Магаданская область & 4,9 & 123,4 & 8,3 & 30,7 \\
\hline Сахалинская область & 15,3 & 107,0 & 6,4 & 6,7 \\
\hline ЕАО & 4,9 & 102,5 & 7,7 & \\
\hline ЧАО & 1,4 & 116,9 & 4,9 & \\
\hline
\end{tabular}

Источник: Социально-экономическое..., 2020.

Рост числа безработных, в первую очередь, был вызван высвобождением работников, сокращением штатов или ликвидацией предприятия, закрытием индивидуальными предпринимателями собственного дела. Численность безработных, объяснявших это как основную причину незанятости, в 2020 г. увеличилась более чем на $30 \%{ }^{2}$. Важно отметить, что численность безработных, не имеющих опыта работы, сократилась на 6,6\% по сравнению с 2019 г. Это может свидетельствовать о том, что в 2020 г. не произошло роста «молодежной безработицы», вызванного притоком соответствующих возрастных групп на ослабленный пандемией рынок труда (Полякова и др., 2020). Кроме этого, введение новых правил выплат пособий по безработице в середине 2020 г. привело к увеличению числа безработных, обратившихся в органы службы занятости. Численность официально зарегистрированных безработных на конец года составила 136,5 тыс. чел. и увеличилась по сравнению с аналогичным периодом 2019 г. в 2,8 раза. Уровень безработицы по-

${ }^{1}$ По методологии МОТ на основании выборочного обследования по проблемам занятости.

2 Итоги выборочного обследования рабочей силы / ФСГС. 2020. URL: https://rosstat.gov.ru/ compendium/document/13265 (дата обращения: апрель 2021). 
высился с 6\% (2019 г.) до 6,5\% при существенной дифференциации по дальневосточным субъектам РФ от 3,8-4\% в Камчатском и Хабаровском краях до 9,8-10,5\% в Забайкальском крае и Республике Бурятия.

В 2020 г. уровень занятости населения ${ }^{1}$ в ДФО составил 64,1\%, что на 0,4 п. п. выше среднероссийского уровня и незначительно (на 0,2 п. п.) лучше показателя 2019 г. Высокий уровень занятости (70-77\%) сохраняется в северных регионах округа (Камчатский край, Магаданская область, ЧАО). В условиях кризисных ограничений работодатели используют практику неполной занятости сотрудников. В IV квартале 2020 г. количество работников, занятых неполное рабочее время, в ДФО увеличилось на 8,2\% по сравнению с аналогичным периодом 2019 г. На фоне сокращения количества работников, находящихся в отпусках без сохранения заработной платы (на 5\%), в 6,1 раза возросло число работников, находящихся в формате вынужденного простоя².

Период продолжительности поиска работы безработными гражданами ДФО сократился до 7,3 месяца (2019 г. - 7,7 месяца) и варьировал в пределах от 4,9 месяца (ЧАО) до 9,6 месяца (Забайкальский край). Сохранилась позитивная динамика в составе безработных: доля ищущих работу более 12 месяцев среди безработных в среднем по ДФО снизилась с 29,8\% в 2019 г. до 26,4\% в 2020 г., но все еще остается высокой в $\mathrm{EAO}(30,7 \%)$ и в Забайкальском крае (48,5\%).

Потребность работодателей в работниках, заявленная в органы службы занятости населения, к концу 2020 г. увеличилась на 7,5\%, и, как следствие, нашла отражение в показателях коэффициента напряженности на рынке труда. Если на конец 2020 г. нагрузка безработными, зарегистрированными в органах службы занятости населения, на 100 заявленных вакансий в среднем по России составляла 170,1 человека, то в Республике Саха (Якутия) - 366,0, в Республике Бурятия - 204,4.

По оценкам аналитиков, рост числа вакансий наблюдается в таких ключевых отраслях экономики Дальнего Востока, как строительство, добывающие отрасли, судостроение и судоремонт, на которые приходится более $80 \%$ заявленных вакансий ${ }^{3}$.

\footnotetext{
${ }^{1}$ Отношение численности занятого населения к общей численности населения в возрасте 15-72 лет.

2 В 2020 г. были установлены нерабочие дни с сохранением за работниками заработной платы (О мерах по обеспечению санитарно-эпидемиологического благополучия населения на территории Российской Федерации в связи с распространением новой коронавирусной инфекции (COVID-19): указ Президента Российской Федерации от 02 апреля 2020 г. № 239. URL: http:// publication.pravo.gov.ru/Document/View/0001202004020025 (дата обращения: апрель 2021); Об объявлении в Российской Федерации нерабочих дней: указ Президента Российской Федерации от 25 марта 2020 г. № 206. URL: http://www.consultant.ru/document/cons doc LAW 348485/ (дата обращения: апрель 2021).

3 Агентство по развитию человеческого капитала на Дальнем Востоке и в Арктике. 2021. URL: https://hcfe.ru/job-in-the-far-east/ (дата обращения: январь 2021).
} 


\section{ВНЕШНЕЭКОНОМИЧЕСКОЕ СОТРУДНИЧЕСТВО}

\section{Прямые иностранные инвестиции}

В настоящее время статистика по прямым иностранным инвестициям (ПИИ) в России формируется Центральным банком РФ. В нее включены данные по накопленным ПИИ субъектов РФ, структуре инвестиций по странам, географическим и экономическим зонам прямых инвесторов, видам экономической деятельности. В таблице 13 представлены данные по поступлению ПИИ по регионам ДФО в 2019 г. и за 9 месяцев 2020 г.

Поступление прямых инвестиций в ДФО*

Таблица 13

в 2019-2020 гг., млн долл. / \%

Table 13

Foreign direct investment inflow in the the Far Eastern Federal District regions* in 2019-2020, USD $\mathrm{mln} /$ in \%

\begin{tabular}{l|c|c}
\hline \multicolumn{1}{c|}{ Территория } & 2019 & $2020(9$ мес.) \\
\hline ДФО & $6770 / 100$ & $4070 / 100$ \\
\hline Республика Бурятия & $199 / 2,94$ & $0 / 0$ \\
\hline Республика Саха (Якутия) & $1168 / 17,25$ & $1036 / 25,45$ \\
\hline Забайкальский край & $112 / 1,65$ & $80 / 1,97$ \\
\hline Камчатский край & $55 / 0,81$ & $88 / 2,17$ \\
\hline Приморский край & $415 / 6,13$ & $261 / 6,42$ \\
\hline Хабаровский край & $576 / 8,51$ & $90 / 2,22$ \\
\hline Амурская область & $317 / 4,69$ & $190 / 4,67$ \\
\hline Магаданская область & $10 / 0,15$ & $4 / 0,1$ \\
\hline Сахалинская область & $3835 / 56,65$ & $2280 / 56,02$ \\
\hline ЕАО & $35 / 0,52$ & $0,2 / 0,01$ \\
\hline ЧАО & $47 / 0,7$ & $37 / 0,92$ \\
\hline
\end{tabular}

Примечание: * - данные без учета изъятия прямых инвестиций.

Источник: Центральный банк России.

Как видно из данных таблицы 13, а также данных о накопленных объемах прямых иностранных инвестиций (табл. 15), Сахалинская область остается безусловным лидером среди регионов ДФО по их привлечению. Этот регион стабильно получает более половины от всего объема поступлений ПИИ в ДФО. По итогам 9 месяцев 2020 г. иностранные инвесторы «не отметились» в Республике Бурятия, минимальные доли поступающих объемов ПИИ показали ЕАО, ЧАО, Магаданская область. Более высокие показатели поступающих ПИИ наблюдались в остальных субъектах ДФО, включающих Забайкальский, Хабаровский и Камчатский края. Стабильное привлечение ПИИ было отмечено в Республике Саха (Якутия) и Приморском крае. Отметим, что по данным за 9 месяцев 2020 г. так называемое «чистое привлечение» 
ПИИ 1,763 млрд долл. (сальдо поступивших и изъятых прямых инвестиций) составило 80\% от годового сальдо 2019 г. Это сальдо не для всех регионов ДФО сопоставимо с объемами поступивших ПИИ (см. табл. 13 и 14). В целом по ДФО за 9 месяцев 2020 г. объемы поступающих ПИИ составили 4,070 млрд долл., что эквивалентно 60\% объемов ПИИ за 2019 г.

\section{Сальдо поступления прямых инвестиций в ДФО}

Таблийа 14 в 2019-2020 гг., млн долл.

Table 14

Net foreign direct investment inflow

in the Far Eastern Federal District regions, 2019-2020, USD mln

\begin{tabular}{l|c|c}
\hline \multicolumn{1}{c|}{ Территория } & 2019 & 2020 (9 мес.) \\
\hline ДФО & 2196 & 1763 \\
\hline Республика Бурятия & 59 & 0 \\
\hline Республика Саха (Якутия) & -50 & 472 \\
\hline Забайкальский край & -4 & 4 \\
\hline Камчатский край & 4 & 12 \\
\hline Приморский край & 175 & 84 \\
\hline Хабаровский край & -149 & 16 \\
\hline Амурская область & 208 & -2 \\
\hline Магаданская область & -92 & 1023 \\
\hline Сахалинская область & 1964 & 0 \\
\hline ЕАО & 35 & 15 \\
\hline ЧАО & 47 & \\
\hline
\end{tabular}

Примечание: данные представлены в соответствии с принципом активов / пассивов (с учетом изъятия прямых инвестиций в отчетном году). Знак сальдо операций по строке «Прямые инвестиции»: «+» означает превышение активов над обязательствами; «-» означает превышение обязательств над активами.

Источник: Центральный банк России.

По данным таблицы 15 видны как общие остатки ПИИ (то есть накопленные обязательства субъектов по инвестициям), так и остатки по видам прямых инвестиций (участие в капитале и долговые инструменты). К настоящему времени наиболее масштабными вложениями ПИИ являются объекты дальневосточного энергетического сектора, как в сфере добычи, так и переработки, транспортировки газа и нефти. По этим причинам к началу 2020 г. доля Сахалинской области составляла порядка 86\% в общих остатках ПИИ в ДФО. При этом подавляющий объем привлекаемых ПИИ в округе по типу инвестиций связан с прямым участием в капитале компаний.

Что касается долговых инструментов, то основными реципиентами данного типа ПИИ на Дальнем Востоке являются организации Приморского и Забайкальского краев, Республики Саха (Якутия), Сахалинской области, Республики Бурятия. 
Прямые иностранные инвестиции в ДФО

Таблица 15 (остатки в разрезе инструментов), млн долл.

Table 15

Foreign direct investments stock in the Far Eastern Federal District regions (by investment instruments), USD mln

\begin{tabular}{l|c|c|c|c|c|c}
\hline \multirow{2}{*}{ Территория } & \multicolumn{3}{c|}{ На 01.01.2020 } & \multicolumn{3}{c}{ На 01.10.2020 } \\
\cline { 2 - 7 } & всего & $\begin{array}{c}\text { участие } \\
\text { в капи- } \\
\text { тале }\end{array}$ & $\begin{array}{c}\text { долговые } \\
\text { инстру- } \\
\text { менты }\end{array}$ & $\begin{array}{c}\text { участие } \\
\text { в капи- } \\
\text { тале }\end{array}$ & $\begin{array}{c}\text { долговые } \\
\text { инстру- } \\
\text { менты }\end{array}$ \\
\hline ДФО & 73995 & 69265 & 4730 & 62428 & 57240 & 5188 \\
\hline Республика Бурятия & 301 & 18 & 283 & 303 & 21 & 282 \\
\hline Республика Саха (Якутия) & 2510 & 1418 & 1092 & 2703 & 1086 & 1617 \\
\hline Забайкальский край & 1487 & 1029 & 458 & 1506 & 1045 & 461 \\
\hline Камчатский край & 229 & 184 & 45 & 155 & 32 & 123 \\
\hline Приморский край & 3269 & 1911 & 1358 & 2737 & 1457 & 1280 \\
\hline Хабаровский край & 647 & 362 & 285 & 525 & 267 & 258 \\
\hline Амурская область & 966 & 904 & 62 & 670 & 621 & 50 \\
\hline Магаданская область & 7 & -2 & 9 & 6 & -1 & 7 \\
\hline Сахалинская область & 63988 & 62983 & 1006 & 53293 & 52304 & 989 \\
\hline ЕАО & 218 & 97 & 120 & 155 & 60 & 95 \\
\hline ЧАО & 373 & 361 & 13 & 375 & 348 & 27 \\
\hline
\end{tabular}

Примечание: данные представлены в соответствии с принципом активов / пассивов (как в табл. 14).

Источник: Центральный банк России.

Так, к началу 2020 г. накопленный объем (или остатки) ПИИ в дальневосточной экономике составил порядка 73,995 млрд долл. При этом на Дальнем Востоке отмечается существенная отраслевая асимметрия в привлечении ПИИ. Подавляющая часть (порядка 89\% к началу 2020 г.) накопленных прямых иностранных инвестиций концентрируется в добыче топливно-энергетических полезных ископаемых вместе с геологоразведкой, а остальная - в обрабатывающих производствах, пищевой промышленности, транспортировке и хранении. В третичном секторе экономики ПИИ были сосредоточены главным образом в предоставлении профессиональных, научных и технических услуг, операциях с недвижимым имуществом (табл. 16).

Распределение накопленных ПИИ в ДФО по странам-источникам инвестиций указывает на то, что за 9 месяцев 2020 г. основными источниками привлечения ПИИ в округе (табл. 17) оставались офшорные территории и прочие источники (категория «не распределено по странам» при наличии 
так называемых конфиденциальных данных). Это можно объяснить сохранением каналов финансирования крупнейших нефтегазовых и других проектов через офшорные юрисдикции, чем объясняется и незаметная доля Японии как страны-инвестора, несмотря на участие компаний этой страны в сахалинских проектах. Так, по данным таблицы 17 о накопленных ПИИ в макрорегионе на 01.10.2020 г. видно, что источником 87\% поступивших ПИИ на Дальний Восток являются офшоры, такие как Багамы, Бермуды, Кипр, тогда как на страны Северо-Восточной Азии пришлось лишь 1,4\%.

Таблицуа 16

Прямые иностранные инвестиции в ДФО

(остатки по видам экономической деятельности), млн долл.

Table 16

Foreign direct investments stock in the Far Eastern Federal District (by type of economic activity), USD mln

\begin{tabular}{l|c|c}
\hline \multicolumn{1}{c|}{ Вид деятельности } & На 01.01.2020 & На 01.10.2020 \\
\hline Всего & 73995 & 62428 \\
\hline $\begin{array}{l}\text { Деятельность в области культуры, спорта, досуга и развле- } \\
\text { чений }\end{array}$ & 128 & 81 \\
\hline $\begin{array}{l}\text { Деятельность гостиниц и предприятий общественного } \\
\text { питания }\end{array}$ & 3 & 3 \\
\hline Деятельность по операциям с недвижимым имуществом & 280 & 239 \\
\hline Деятельность профессиональная, научная и техническая & 1240 & 1133 \\
\hline Деятельность финансовая и страховая & 0 & 170 \\
\hline Добыча полезных ископаемых & 66381 & 55123 \\
\hline Обрабатывающие производства & 264 & 248 \\
\hline Сельское, лесное хозяйство, охота и рыболовство & 88 & 112 \\
\hline Строительство & 92 & 80 \\
\hline $\begin{array}{l}\text { Торговля оптовая и розничная; ремонт автотранспортных } \\
\text { средств и мотоциклов }\end{array}$ & 144 & -6 \\
\hline Транспортировка и хранение & 1458 & 1071 \\
\hline Не распределено по видам экономической деятельности & 3917 & 4174 \\
\hline
\end{tabular}

Примечания. Данные включают инвестиции в банки и прочие сектора; в графу «Не распределено по видам экономической деятельности» включены конфиденциальные данные. Данные ЦБ РФ в таблицах 15-16 соответствуют методологии шестого издания «Руководства по платежному балансу и международной инвестиционной позиции» МВФ и представлены в соответствии с принципом активов / пассивов. Определение видов экономической деятельности соответствует основным классификационным категориям четвертого, пересмотренного варианта Международной стандартной отраслевой классификации ООН (ISIC4) и ее европейского эквивалента (NACE2). Данные по хозяйствующим субъектам, получающим прямые инвестиции, были изначально сформированы на базе Общероссийского классификатора видов экономической деятельности (ОКВЭД) по основному виду деятельности и затем перегруппированы по методологии ISIC4. Начиная с данных на 01.04.2017 г. используется ОКВЭД2. Основным видом экономической деятельности коммерческой организации является тот вид, который по итогам предыдущего года имеет наибольший удельный вес в общем объеме выпущенной продукции и услуг.

Источник: Центральный банк России. 
Географическая структура накопленных ПИИ в ДФО, млн долл.

Geographical composition of the foreign direct investments stock in the Far Eastern Federal District, USD mln

\begin{tabular}{l|c|c}
\hline \multicolumn{1}{c|}{ Страна } & На 01.01.2020 & На 01.10 .2020 \\
\hline Всего & 73995 & 62428 \\
\hline Багамы & 25862 & 21295 \\
\hline Бермуды & 36939 & 30294 \\
\hline Кипр & 4530 & 2912 \\
\hline Не распределено, в том числе конфиденциальные данные & 4642 & 5448 \\
\hline Прочие страны, в том числе: & 3677 & 2479 \\
\hline Китай & 566 & 547 \\
\hline Республика Корея & 212 & 178 \\
\hline Япония & 187 & 168 \\
\hline
\end{tabular}

Примечание: включены инвестиции в банки и прочие сектора.

Источник: Центральный банк России.

В последние годы предпринимались усилия по изменению сложившейся «инвестиционной географии» привлечения ПИИ. Это является безусловным приоритетом проведения с 2013 г. Россией на Востоке особой государственной политики (так называемой Новой Азиатской политики), направленной, в частности, на повышение доходности и снижение рисков реализации проектов иностранных инвесторов на Дальнем Востоке.

Существенным элементом реализуемой программы является создание на Дальнем Востоке России специальных институциональных режимов (обособленных площадок для создания инвесторами новых производств) «территория опережающего развития» (ТОР), «свободный порт Владивосток» (СПВ), «специальный административный район» (САР); предоставление грантов инвесторам на развитие инфраструктуры; реализация иных мер на основе лучших мировых практик поддержки иностранных инвесторов.

К 2020 г. на территории Дальнего Востока была проведена активная работа по формированию и развитию новых преференциальных институтов: здесь создано 18 ТОР, 25 муниципальных образований получили возможность использования режима СПВ, на острове Русский зарегистрирован САР. На всех территориях инвесторам предоставляются существенные налоговые и таможенные льготы, на постоянной основе действуют эффективные финансовые и организационные преференции. В результате интенсивного государственного стимулирования и постепенного улучшения делового климата на Дальнем Востоке России инвесторы из практически всех стран АТР начинают наращивать свое присутствие в регионе (табл. 18). 


\section{Проекты с иностранными инвесторами в ТОР и СПВ в ДФО по лидирующим странам}

Таблицьа 18

Table 18

Projects with foreign investors in the Advanced development zones (TOR) and the Free port of Vladivostok (SPV) in the Far Eastern Federal District, by leading countries

\begin{tabular}{l|c|c|c|c}
\hline \multirow{2}{*}{ Страна } & \multicolumn{2}{c}{ Объем инвестиций, млн руб. } & \multicolumn{2}{c}{ Количество проектов } \\
\cline { 2 - 5 } & на начало 2019 & на начало 2020 & на начало 2019 & на начало 2020 \\
\hline Всего & 164160 & 266490 & 31 & 34 \\
\hline Китай & 129600 & 227997 & 12 & 11 \\
\hline Япония & 8640 & 11844 & 7 & 6 \\
\hline Республика Корея & 2160 & 2665 & 2 & 5 \\
\hline Австралия & 2160 & 2665 & 3 & 3 \\
\hline Сингапур & 2160 & 2665 & 1 & 1 \\
\hline Вьетнам & 15120 & 14805 & 1 & 64 \\
\hline Всего & & $C П B$ & & 41 \\
\hline Китай & 36924 & 104202 & 50 & 6 \\
\hline Республика Корея & 27693 & 73603 & 33 & 4 \\
\hline Япония & 2172 & 4135 & 6 & 2 \\
\hline Сингапур & 543 & 3308 & 3 & 1 \\
\hline Вьетнам & 1086 & 8270 & 1 & 3 \\
\hline Индия & 543 & 8270 & 1 & \\
\hline
\end{tabular}

Источник: данные Корпорации развития Дальнего Востока и Арктики.

Среди стран-инвесторов как по объемам финансирования, так и по количеству проектов, реализуемых на российском Дальнем Востоке, с большим отрывом от других партнеров лидирует Китай. Инвестиционное сотрудничество с этой страной стало заметной составляющей в общей сумме ПИИ, направляемых в ДФО. Китайские инвестиции составили более 50\% от общего объема иностранных вложений в ТОР и СПВ. В ТОР и СПВ с участием инвесторов из КНР заявлено к реализации более 50 инвестиционных проектов, часть из них уже реализуется. Заметным является присутствие китайских компаний и в общем инвестиционном процессе. Так, на начало 2020 г. доля КНР в общем объеме инвестиций в ТОР составляла 7,7\%, в доле в создаваемых рабочих местах - 4,9\%. В СПВ Китай представлен 8,9\% в общем объеме инвестиций, при этом доля в создаваемых рабочих местах $-14,4 \%$. При этом важной характеристикой осуществляемых китайских инвестиций является их диверсифицированная структура. В подавляющем большинстве они представляют частные инвестиции, основная доля из которых не связана с добычей природных ресурсов. Это вложения в обрабатывающие производства, логистику и транспорт, сельское хозяйство, туризм и другие сектора. 


\section{ВНЕШНЯЯ ТОРГОВЛЯ}

В 2020 г. внешнеторговый оборот ДФО уменьшился на 13,6\% - до 32 114,4 млн долл. (2019 г. - 37 163,4 млн долл.). Экспорт уменьшился на 16,4\% - до 24054 млн долл. (2019 г. - 28 780,1 млн долл.), импорт - на 3,9\% - до 8060,4 млн долл. (2019 г. - 8383,3 млн долл.), что вызвало очередное сокращение положительного сальдо торгового баланса макрорегиона (puc. 2). Негативные тенденции во внешней торговле были вызваны значительным снижением мировых цен на топливо, а также мировой рецессией, снижением мирового спроса на товары и услуги, ослаблением рубля относительно доллара и евро.

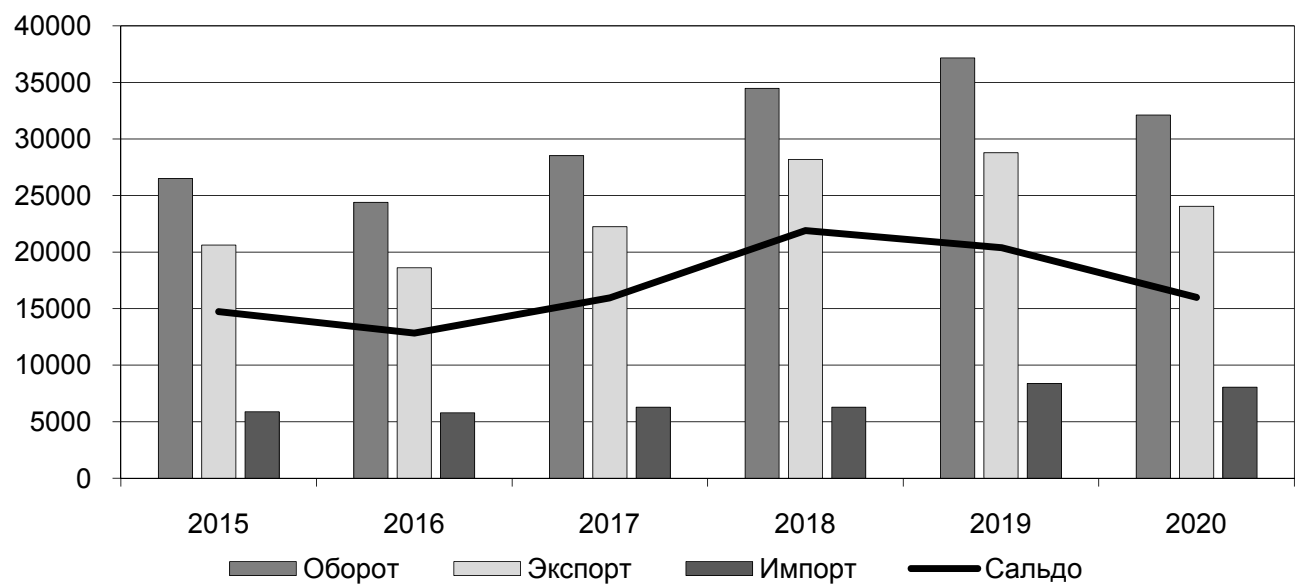

Puc. 2. Динамика внешней торговли ДФО, млн долл.

Fig. 2. Dynamics of foreign trade of the Far Eastern Federal District, USD mln

Источник: здесь и далее в разделе: составлено по: Внешняя торговля Российской Федерации / Дальневосточная таможенная служба. 2021. URL: https://dvtu.customs.gov.ru/statistic (дата обращения: апрель 2021).

Несмотря на значительное уменьшение поставок, структура экспорта ДФО в 2020 г. не изменилась: более половины экспорта макрорегиона было представлено продукцией ТЭК, значительная часть экспортных поставок состояла из рыбной продукции, древесины и целлюлозно-бумажных изделий.

Динамика экспорта ДФО в 2020 г. отражает общероссийские тенденции (Божечкова и др., 2021; Кнобель, Фиранчук, 2021). В связи со снижением среднегодовых контрактных цен на нефть, нефтепродукты, природный газ, металлы и другие базовые товары российского экспорта уменьшился стоимостной объем экспортных поставок макрорегиона: продукции ТЭК - на $26,5 \%$, древесины и целлюлозно-бумажных изделий - на 17,4\%, рыбной продукции - на 1,6\% (табл. 19). 
Товарная структура экспорта ДФО

Таблица 19

Table 19

Export commodity structure in the Far Eastern Federal District

\begin{tabular}{|c|c|c|c|c|}
\hline \multirow{2}{*}{ Товарная группа } & \multicolumn{2}{|c|}{2019} & \multicolumn{2}{|c|}{2020} \\
\hline & млн долл. & $\%$ & млн долл. & $\%$ \\
\hline Экспорт, всего & 28780,1 & 100,0 & 24054,0 & 100,0 \\
\hline $\begin{array}{l}\text { Топливо, минеральное сырье, } \\
\text { металлы }\end{array}$ & 18636,9 & 64,8 & 14711,2 & 61,2 \\
\hline продукция ТЭК & 16957,0 & 58,9 & 12470,4 & 51,8 \\
\hline Продовольственные товары & 4013,0 & 13,9 & 4030,5 & 16,8 \\
\hline рыбная продукция & 3526,7 & 12,3 & 3469,5 & 14,4 \\
\hline $\begin{array}{l}\text { Древесина и целлюлозно-бумаж- } \\
\text { ные изделия }\end{array}$ & 1140,0 & 4,0 & 942,1 & 3,9 \\
\hline $\begin{array}{l}\text { Машины, оборудование, транс- } \\
\text { портные средства }\end{array}$ & 1283,9 & 4,5 & 689,2 & 2,9 \\
\hline Прочие & 3706,2 & 12,9 & 3681,0 & 15,3 \\
\hline
\end{tabular}

Структура импорта ДФО в 2020 г. также сохранилась. Импорт попрежнему состоял в основном из продукции машиностроения, продовольственных и химических товаров, металлов и изделий из них. Практически по всем товарным позициям импорта макрорегиона наблюдалось уменьшение объемов. Так, объем импорта продукции машиностроения в 2020 г. уменьшился на 2,6\% по сравнению с 2019 г., продовольственных товаров на $29,7 \%$, химических товаров - на $5,8 \%$, металлов и изделий из них - на 10,7\% (табл. 20).

Таблийа 20

\section{Товарная структура импорта ДФО}

Table 20

Import commodity structure in the Far Eastern Federal District

\begin{tabular}{l|c|c|c|c}
\hline \multirow{2}{*}{ Товарная группа } & \multicolumn{2}{c|}{2019} & \multicolumn{2}{c}{2020} \\
\cline { 2 - 5 } & млн долл. & $\%$ & млн долл. & $\%$ \\
\hline Импорт, всего & 8383,3 & 100,0 & 8060,4 & 100,0 \\
\hline $\begin{array}{l}\text { Машины, оборудование, транспортные } \\
\text { средства }\end{array}$ & 4511,3 & 53,8 & 4394,9 & 54,5 \\
\hline Продовольственные товары & 1057,2 & 12,6 & 743,4 & 9,2 \\
\hline Химические товары & 752,9 & 9,0 & 709,5 & 8,8 \\
\hline Металлы и изделия из них & 683,0 & 8,1 & 610,0 & 7,6 \\
\hline Текстиль, текстильные изделия и обувь & 311,4 & 3,7 & 438,1 & 5,4 \\
\hline Прочие & 1067,3 & 12,7 & 1164,6 & 14,4 \\
\hline
\end{tabular}

Территориальная структура внешней торговли остается стабильной и после включения в состав ДФО двух дополнительных субъектов РФ. Ли- 
дерами по обороту в 2020 г. были Сахалинская область, Приморский край, Республика Саха (Якутия), Хабаровский край (табл. 21).

Таблийа 21

Территориальная структура внешней торговли ДФО, \%

Table 21

Territorial export structure in the Far Eastern Federal District, in \%

\begin{tabular}{l|c|c|c|c|c|c}
\hline \multirow{2}{*}{ Территория } & \multicolumn{3}{|c|}{2019} & \multicolumn{3}{c}{2020} \\
\cline { 2 - 7 } & экспорт & импорт & оборот & экспорт & импорт & оборот \\
\hline ДФО & 100 & 100 & 100 & 100 & 100 & 100 \\
\hline Сахалинская область & 52,8 & 11,3 & 43,4 & 47,1 & 11,2 & 38,1 \\
\hline Приморский край & 14,1 & 62,1 & 25,0 & 11,8 & 63,1 & 24,7 \\
\hline Республика Саха (Якутия) & 14,1 & 3,4 & 11,7 & 14,3 & 1,2 & 11,0 \\
\hline Хабаровский край & 6,4 & 10,4 & 7,3 & 7,5 & 9,7 & 8,1 \\
\hline Забайкальский край & 2,2 & 4,5 & 2,7 & 4,5 & 5,5 & 4,7 \\
\hline Республика Бурятия & 3,2 & 1,1 & 2,7 & 4,8 & 0,9 & 3,8 \\
\hline Камчатский край & 3,0 & 2,1 & 2,8 & 3,4 & 2,8 & 3,3 \\
\hline Амурская область & 1,7 & 3,3 & 2,0 & 2,7 & 3,4 & 2,9 \\
\hline Магаданская область & 1,6 & 0,8 & 1,4 & 1,9 & 1,0 & 1,7 \\
\hline ЧАО & 0,6 & 0,6 & 0,6 & 1,2 & 1,0 & 1,2 \\
\hline ЕАО & 0,4 & 0,3 & 0,4 & 0,8 & 0,1 & 0,6 \\
\hline
\end{tabular}

Динамика показателей внешней торговли дальневосточных субъектов РФ обусловлена сложившейся товарной структурой экспорта и импорта. Так, через Сахалинскую область ${ }^{1}$ поставляется большая часть экспортной продукции ТЭК макрорегиона (2020 г. - 84,3\%, 2019 г. - 83,4\%), что объясняет резкое уменьшение экспорта области в 2020 г. Через Приморский край поставляется большая часть экспорта рыбной продукции $(42,8 \% ; 39,5 \%)$ и лесотоваров $(33,3 \% ; 35,5 \%)$. Через Хабаровский край поставляется около половины экспорта лесотоваров $(49,8 \% ; 45,9 \%)$ и значительная часть экспорта рыбной продукции $(12,1 \% ; 10,1 \%)$.

Большая часть импорта ДФО в 2020 г. традиционно поступила в Приморский край, Сахалинскую область и Хабаровский край (см. табл. 21).

Географическая структура внешней торговли ДФО также сохранилась. Главными странами-партнерами, определяющими динамику внешней торговли макрорегиона на протяжении многих лет, являются КНР, Республика Корея и Япония (CBA-3). В 2020 г. доля стран СВА-3 составила 75,4\% от всего внешнеторгового оборота ДФО (2019 г. - 75,1\%), было зафиксировано уменьшение оборота со странами Евросоюза, НАФТА, АСЕАН и увеличение оборота со странами СНГ (табл. 22).

\footnotetext{
1 Экспорт продукции через таможенный пункт.
} 
Динамика внешней торговли ДФО

Таблиияа 22 с отдельными странами и объединениями, \%

Dynamics of foreign trade of the Far Eastern Federal District with individual countries and associations, $\%$

\begin{tabular}{l|c|c|c|c|c|c}
\hline \multirow{2}{*}{ Объединения и страны } & \multicolumn{3}{|c|}{2019} & \multicolumn{3}{c}{2020} \\
\cline { 2 - 7 } & экспорт & импорт & оборот & экспорт & импорт & оборот \\
\hline Всего & 100,0 & 100,0 & 100,0 & 100,0 & 100,0 & 100,0 \\
\hline СВА & 76,6 & 71,2 & 75,4 & 77,6 & 70,0 & 75,7 \\
\hline КНР & 22,4 & 47,9 & 28,2 & 28,8 & 48,5 & 33,8 \\
\hline Республика Корея & 32,7 & 8,4 & 27,2 & 29,7 & 8,2 & 24,3 \\
\hline Япония & 21,1 & 14,8 & 19,7 & 18,8 & 13,4 & 17,4 \\
\hline ЕС27 & 6,6 & 8,0 & 6,9 & 5,8 & 8,9 & 6,5 \\
\hline НАФТА & 0,8 & 5,4 & 1,8 & 0,4 & 4,7 & 1,5 \\
\hline США & 0,5 & 4,8 & 1,5 & 0,4 & 4,0 & 1,3 \\
\hline АСЕАН & 2,2 & 2,2 & 2,2 & 1,6 & 1,9 & 1,7 \\
\hline СНГ & 2,0 & 4,4 & 2,6 & 3,3 & 6,0 & 3,9 \\
\hline Прочие & 11,8 & 8,9 & 11,1 & 11,3 & 8,5 & 10,6 \\
\hline
\end{tabular}

Примечание: СВА - страны Северо-Восточной Азии (КНДР, КНР, Монголия, Республика Корея, Япония), ЕС27 - 27 стран Европейского союза, НАФТА - страны, входящие в Североамериканское соглашение о свободной торговле (Канада, Мексика, США), АСЕАН - 10 странучастниц Ассоциации государств Юго-Восточной Азии.

Экспорт ДФО в основном направляется в страны СВА-3, что отличается от общероссийских тенденций ${ }^{1}$ В 2020 г. экспортные поставки основных товарных позиций распределились следующим образом. Продукция ТЭК: Республика Корея - 42,1\%, Япония - 31,9\%, КНР - 18,5\%; рыбная продукция: Республика Корея - 46,2\%, КНР - 42,9\%, Япония - 6,5\%; продукция лесопромышленного комплекса: КНР - 80,6\%, Япония - 11,3\%, Республика Корея $-5,2 \%$.

Страны СВА-3 традиционно являются и основными партнерами ДФО по импорту. Значимый вклад в совокупный импорт макрорегиона вносят также США, страны Евросоюза, а в последние годы и страны СНГ (см. табл. 22).

Несмотря на значительное уменьшение объемов экспорта и импорта в 2020 г., товарная, территориальная и географическая структуры внешней торговли ДФО не изменились. Негативные тенденции были вызваны значительным снижением мировых цен на топливо, мировой рецессией, снижением зарубежного спроса, ослаблением рубля относительно доллара и евро.

1 По данным ФТС России, крупнейшими торговыми партнерами РФ по экспорту в 2020 г. являлись КНР (18,3\%), Германия (7,4\%), Нидерланды (5\%), Беларусь (5\%). 


\section{ВЫВОДЫ}

События 2020 г. оказали негативное влияние на «хрупкое» равновесие в экономике ДФО, установившееся в 2018-2019 гг. В результате было отмечено падение основных социально-экономических параметров развития:

- значительное сокращение объема инвестиционных ресурсов (6-49\%) в основных «капиталоемких» субъектах Федерации ДФО: Амурская и Сахалинская области, Приморский край, Республика Саха (Якутия);

- существенная отраслевая асимметрия в привлечении прямых иностранных инвестиций, основная часть которых (около 88\%) концентрируется в геологоразведке и добыче топливно-энергетических полезных ископаемых; сырьевая структура экономики и стратегический интерес инвесторов к месторождениям полезных ископаемых не предполагают существенного изменения объемов поступления ПИИ в ДФО;

- снижение объема производства в промышленном комплексе темпами, превышающими среднероссийские параметры; отрицательное влияние макроэкономических шоков (в том числе сокращение товарооборота с Китаем в результате введения ограничений на трансграничные взаимодействия, ограничения на ввоз иностранной рабочей силы по квотам) оказало негативное влияние на деятельность предприятий машиностроения, нефтепереработки, промышленности строительных материалов в Приморском и Хабаровском краях;

- снижение объема производства в строительном комплексе в большинстве регионов ДФО как в результате сокращения финансирования, так и в недостаточном количестве строительных организаций, способных качественно и своевременно выполнять запланированные работы;

- снижение показателей в работе пассажирских перевозок на фоне роста грузоперевозок железнодорожным и морским видами транспорта; отмечено невыполнение планов развития инфраструктуры железных дорог Восточного полигона, что в условиях роста грузовых потоков в направлении морских портов Дальневосточного бассейна привело к ограничениям возможностей грузоотправителей;

- сокращение реальных денежных доходов населения во всех (кроме Камчатского края, Магаданской области и ЧАО) дальневосточных субъектах РФ после двухлетнего слабоположительного роста, в результате чего Дальний Восток продолжает терять привлекательность в сфере высоких доходов населения;

- сохранение тенденций уменьшения численности населения не только за счет миграционного оттока, но и естественной убыли в результате как факторов объективного снижения рождаемости, так и социальных и экономических последствий пандемии. 


\section{СПИСОК ЛИТЕРАТУРЫ}

Аганбегян А.Г. Предложения по социально-экономическому развитию в современной кризисной обстановке // Экономическое возрождение России. 2020. № 2 (64). C. 33-44. https://doi.org/10.37930/1990-9780-2020-2-64-33-44

Асеева Т.А., Киселев Е.П., Сухомиров Г.И. Сельское хозяйство Дальнего Востока: условия, проблемы и потенциал развития / под ред. Н.Е. Антоновой; ИЭИ ДВО РАН; ДальНИИСХ ХФИЦ ДВО РАН. Хабаровск: ИЭИ ДВО РАН, 2020. 162 с.

Божечкова А.В., Кнобель А.Ю., Трунин П.В. Платежный баланс: итоги 2020 года // Экономическое развитие России. 2021. Т. 28. № 2. С. 4-8.

Божечкова А.В., Трунин П.В. Денежно-кредитная политика и инфляция: итоги 2020 г. // Экономическое развитие России. 2021. Т. 28. № 1. С. 4-6.

Буторина O.B. Экономическая система ЕС под прессом пандемии: возможности и пределы трансформации // Контуры глобальных трансформаций: политика, экономика, право. 2020. Т. 13. № 4. С. 144-162. https://doi.org/10.23932/2542-02402020-13-4-7

Информация для ведения мониторинга социально-экономического положения субъектов Российской Федерации / ФСГС. 2021. URL: https://rosstat.gov.ru/folder/11109/ document/13259 (дата обращения: март 2021).

Кнобель А.Ю., Фиранчук А.С. Внешняя торговля в 2020 г.: преодоление падения // Экономическое развитие России. 2021. Т. 28. № 3. С. 12-17.

Кузнецова O.B. Уязвимость структуры региональных экономик в кризисных условиях // Федерализм. 2020. № 2. С. 20-38. https://doi.org/10.21686/2073-1051-20202-20-38

Кузнецова О.В., Бадина С.В., Михайлов А.А., Бобровский Р.О. Тенденции развития и модернизации промышленности регионов России. Итоги IV квартала 2020 г. // Pocсийский экономический университет им. Г.В. Плеханова. 2021. Вып. 2. 18 с. URL: https://www.rea.ru/ru/events/SiteAssets/bul-prom.pdf (дата обращения: апрель 2021).

Минакир П.А. Экономика пандемии: дальневосточный аспект // Пространственная экономика. 2020. Т. 16. № 4. C. 7-22. https://doi.org/10.14530/se.2020.4.007-022

Михеева Н.Н. Устойчивость российских регионов к экономическим шокам // Проблемы прогнозирования. 2021. № 1. С. 116-118. https://doi.org/10.47711/0868-6351184-106-118

Найден С.Н. Социальный потенциал регионов Дальнего Востока: пространственный разрыв // Регионалистика. 2020. Т. 7. № 6. С. 66-83. http://dx.doi.org/10.14530/ reg.2020.6.66

Полякова А.Г., Елисеева М.А., Лямок В.Ю. Социально-экономическая ситуация между первой и второй волной пандемии: итоги третьего квартала 2020 г. // Экономическое развитие России. 2021. Т. 28. № 1. С. 64-76.

Прокапало О.М., Бардаль А.Б., Исаев А.Г., Мазитова М.Г., Суслов Д.В. Экономическая конъюнктура в Дальневосточном федеральном округе в 2019 г. // Пространственная экономика. 2020. Т. 16. № 2. С. 142-184. https://dx.doi.org/10.14530/ se.2020.2.142-184

Регионы России. Социально-экономические показатели. 2020 / ФСГС. 2020. URL: https://rosstat.gov.ru/folder/210/document/13204 (дата обращения: апрель 2020).

Социально-экономическое положение Дальневосточного федерального округа. 2020 / ФСГС. 2020. URL: https://rosstat.gov.ru/folder/11109/document/13260 (дата обращения: март 2021).

Социально-экономическое положение России. Январь 2021 / ФСГС. 2021. URL: https://rosstat.gov.ru/compendium/document/50801 (дата обращения: март 2021). 
Сухомиров Г.И. Проблемы развития сельского хозяйства в ДФО // Регионалистика. 2015. Т. 2. № 3. С. 39-50. http://dx.doi.org/10.14530/reg.2015.3

Сухомиров Г.И. Рисоводство на Дальнем Востоке России: развитие, проблемы, перспективы // Регионалистика. 2018. Т. 5. № 5. С. 45-57. http://dx.doi.org/10.14530/ reg.2018.5.45

Терновский Д.С., Шагайда Н.И. Сельское хозяйство в период пандемии // Экономическое развитие России. 2021. Т. 28. № 1. С. 24-28.

Тихоокеанская Россия - 2030: сценарное прогнозирование регионального развития / под ред. П.А. Минакира; Институт экономических исследований ДВО РАН. Хабаровск: ДВО РАН, 2010. $560 \mathrm{c.}$

Тринадцать тезисов об экономике / Центр макроэкономического анализа и краткосрочного прогнозирования. 2020. URL: www.forecast.ru/_ARCHIVE/ Mon_13/2021/1_132021.pdf (дата обращения: апрель 2021).

Хасанова̄ Р.P., Зубаревич Н.В. Рождаемость, смертность населения и положение регионов в начале второй волны пандемии // Экономическое развитие России. 2021. T. 28. № 1. С. 77-87.

\section{REFERENCES}

Aganbegyan A.G. Suggestions on Socio-Economic Development in the Context of the Current Crisis. Ekonomicheskoe Vozrozhdenie Rossii = Economic Revival of Russia, 2020, no. 2 (64), pp. 33-44. https://doi.org/10.37930/1990-9780-2020-2-64-33-44 (In Russian).

Aseeva T.A., Kiselev E.P., Sukhomirov G.I. Agriculture of the Far East: Conditions, Problems and Development Potential. Edited by N.E. Antonova. ERI FEB RAS, FSBSI FRC ARSRIS. Khabarovsk: ERI FEB RAS, 2020, 162 p. (In Russian).

Bozhechkova A.V., Knobel A.Yu., Trunin P.V. Balance of Payments: Results of 2020. Ekonomicheskoe Razvitie Rossii = Russian Economic Developments, 2021, vol. 28, no. 2, pp. 4-8. (In Russian).

Bozhechkova A.V., Trunin P.V. Monetary Policy and Inflation Rate: The Outcome of 2020. Ekonomicheskoe Razvitie Rossii = Russian Economic Developments, 2021, vol. 28, no. 1, pp. 4-6. (In Russian).

Butorina O.V. The EU Economic System under the Pressure of a Pandemic: Opportunities and Limits of Transformation. Kontury Globalnykh Transformatsiy: Politika, Ekonomika, Pravo = Outlines of Global Transformations: Politics, Economics, Law, 2020, vol. 13, no. 4, pp. 144-162. https://doi.org/10.23932/2542-0240-2020-13-4-7 (In Russian).

Information for Monitoring the Socio-Economic Situation of the Subjects of the Russian Federation. Federal State Statistics Service, 2021. Available at: https://rosstat.gov.ru/ folder/11109/document/13259 (accessed March 2021). (In Russian).

Khasanova R.R., Zubarevich N.V. Birth Rate, Mortality and Situation of Regions at the Onset of the Second Wave of Pandemic. Ekonomicheskoe Razvitie Rossii = Russian Economic Developments, 2021, vol. 28, no. 1, pp. 77-87. (In Russian).

Knobel A.Yu., Firanchuk A.S. Foreign Trade in 2020: Overcoming the Downturn. Ekonomicheskoe Razvitie Rossii = Russian Economic Developments, 2021, vol. 28, no. 3, pp. 12-17. (In Russian).

Kuznetsova O.V. Vulnerability of Regional Economies' Structure in Crisis Conditions. Federalizm $=$ Federalism, 2020, no. 2, pp. 20-38. https://doi.org/10.21686/2073-10512020-2-20-38 (In Russian).

Kuznetsova O.V., Badina S.V., Mikhaylov A.A., Bobrovskiy R.O. Trends in the Development and Modernization of Industry in Russian Regions. Results of the Fourth Quarter 
of 2020. Plekhanov Russian University of Economics, 2021, vol. 2, 18 p. Available at: https://www.rea.ru/ru/events/SiteAssets/bul-prom.pdf (accessed April 2021). (In Russian).

Mikheeva N.N. Resilience of Russian Regions to Economic Shocks. Problemy Prognozirovaniya $=$ Studies on Russian Economic Development, 2021, no. 1, pp. 116-118. https://doi.org/10.47711/0868-6351-184-106-118 (In Russian).

Minakir P.A. The Economy of the Pandemic: A Far Eastern Russian Aspect. Prostranstvennaya Ekonomika = Spatial Economics, 2020, vol. 16, no. 4, pp. 7-22. https://doi. org/10.14530/se.2020.4.007-022 (In Russian).

Naiden S.N. Social Potential of the Regions of the Far East: Spatial Gap. Regionalistica [Regionalistics], 2020, vol. 7, no. 6, pp. 66-83. http://dx.doi.org/10.14530/reg.2020.6.66 (In Russian).

Polyakova A.G., Eliseeva M.A., Lyashok V.YU. Socio-Economic Situation between the First and Second Wave of Pandemic: Q3 2020 Fallout. Ekonomicheskoe Razvitie Rossii = Russian Economic Developments, 2021, vol. 28, no. 1, pp. 64-76. (In Russian).

Prokapalo O.M., Bardal A.B., Isaev A.G., Mazitova M.G., Suslov D.V. Economic Situation in the Far Eastern Federal District in 2019. Prostranstvennaya Ekonomika = Spatial Economics, 2020, vol. 16, no. 2, pp. 142-184. https://dx.doi.org/10.14530/ se.2020.2.142-184 (In Russian).

Regions of Russia. Socio-Economic Indicators. 2020. Federal State Statistics Service, 2020. Available at: https://rosstat.gov.ru/folder/210/document/13204 (accessed April 2020). (In Russian).

Socio-Economic Situation of Russia. January 2021. Federal State Statistics Service, 2021. Available at: https://rosstat.gov.ru/compendium/document/50801 (accessed March 2021). (In Russian).

Socio-Economic Situation of the Far Eastern Federal District. 2020. Federal State Statistics Service, 2020. Available at: https://rosstat.gov.ru/folder/11109/document/13260 (accessed March 2021). (In Russian).

Sukhomirov G.I. Problems of Agriculture Development in the Far Eastern Federal District. Regionalistica [Regionalistics], 2015, vol. 2, no. 3, pp. 39-50. http://dx.doi. org/10.14530/reg.2015.3 (In Russian).

Sukhomirov G.I. Rice Growing in the Russian Far East: Development, Problems, Prospects. Regionalistica [Regionalistics], 2018, vol. 5, no. 5, pp. 45-57. http://dx.doi. org/10.14530/reg.2018.5.45 (In Russian).

Ternovskiy D.S., Shagayda N.I. Agricultural Sector During the Pandemic. Ekonomicheskoe Razvitie Rossii = Russian Economic Developments, 2021, vol. 28, no. 1, pp. 24-28. (In Russian).

The Pacific Russia - 2030: Scenario Forecasting for Regional Development. Edited by P.A. Minakir. Khabarovsk: FEB RAS, 2010, 560 p. (In Russian).

Thirteen Theses on Economics. Center for Macroeconomic Analysis and Short-Term Forecasting, 2020.Available at:www.forecast.ru/_ARCHIVE/Mon_13/2021/1_132021. pdf (accessed April 2021). (In Russian).

Поступила в редакцию / Submitted: 11.05.2021

Принята к публикации / Revised: 20.05.2021

Опубликована online / Published online: 30.06.2021 